\title{
Lietuvos atgrasinimo strategija
}

\begin{abstract}
Lietuvos atgrasinimą strategija - tai grasinimas panaudoti karinę jẻgą siekiant neleisti kitam subjektui, dažniausiai valstybei, daryti tam tikrus veiksmus. Šiame straipsnyje siekiama išsiaiškinti Lietuvos atgrasinimo strategijos pagrindinius principus, ju stipriąsias ir silpnąsias puses, pateikti atgrasinimo efektyvumo stiprinimo būdus ir priemones. Straipsnyje bus pateiktas Lietuvos atgrasinimo potencialo panaudojant karines, ekonomines, politines ir kitas priemones ivertinimas. Ypatingas demesys bus skiriamas Lietuvos apginamumo studijoms, kuriomis remiantis galima nustatyti išplèstinio atgrasinimo Lietuvoje sèkmès sąlygas. Šios analizès pagrindas - naudos ir kaštu, kaip dviejų pagrindinių atgrasinimo strategijos elementu, įvertinimas.
\end{abstract}

\section{Ivadas}

Atgrasinimas yra populiariausia netiesioginės valstybių karinės galios naudojimo strategija. Jo tikslas - netiesiogiai naudojant karinę galią užtikrinti valstybės nacionalinius interesus užkertant kelią nepalankiems kitu valstybiu sprendimams, pavyzdžiui, pradèti ginkluotą konfrontaciją. Atgrasinimo strategijos populiarumas buvo nulemtas objektyvių aplinkybiu - branduoliniu ginklų amžiuje tradicinė gynybos sąvokos prarado anksčiau turètą prasmę, o tradicinės kariavimo strategijos buvo demoralizuotos skaudžių Antrojo pasaulinio karo pamoku. Atgrasinimas tapo populiarus dẻl to, kad iš pirmo žvilgsnio jis tarsi atmetè ir tradicinę karo sąvoką, suminkštino jame glūdintį kariavimo ir žudymo elementą ir leido valstybėms skelbtis vykdant taikos politiką, nenukreiptą prieš kitų valstybių interesus. Todèl neatsitiktinai daugumos pasaulio valstybiu, ju tarpe ir Lietuvos strateginiuose dokumentuose atgrasinimas užima centrinę aši, apie ji sukasi ir valstybiu gynybos planavimas.

Oficialiai atgrasinimo strategija Lietuvoje pirmą kartą buvo deklaruota $2000 \mathrm{~m}$. Valstybės gynimo tarybai patvirtinus Lietuvos karinės gynybos strategiją $^{1}$, nors jo užuomazgos glūdi dar nepriklausomybės aušroje populiarioje pilietinės gynybos koncepcijoje. Dabar galiojančios Nacionalinio saugumo strategija ir Karinè strategija atgrasinimą skelbia vienu pagrindinių strateginių prin-

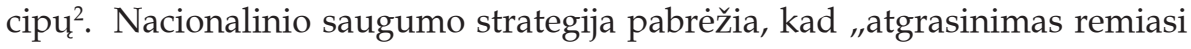

${ }^{*}$ Dr. Vaidotas Urbelis - Vilniaus universiteto Tarptautiniu santykiu ir politikos mokslu instituto desstytojas, Adresas: Vokiečiu 10, 01130 Vilnius, tel. 85 2785206, el. paštas: vaidotasu@post.skynet.lt.

${ }^{1}$ Lietuvos Respublikos karinés gynybos strategija, Vilnius: Leidybos centras prie KAM, 2000.

${ }^{2}$ Lietuvos Respublikos nacionalinio saugumo strategija, Vilnius: KAM Leidybos ir informacinio aprūpinimo tarnyba, 2005; Lietuvos Respublikos karine strategija, Vilnius, KAM Leidybos ir informacinio aprūpinimo tarnyba, 2004. 
Lietuvos Respublikos krašto apsaugos sistemos ir karinių pajėgumų stiprinimu bei NATO kolektyvinės gynybos principais. Stiprus Aljansas yra svarbiausias efektyvų atgrasinimą, o tiesioginės grẻsmės atveju - kolektyvinę gynybą užtikrinantis Lietuvos valstybės saugumo veiksnys".

Lietuvos atgrasinimo strategiją galima padalinti į du skritingus etapus - iki narystės NATO ir po jos. Iki $2004 \mathrm{~m}$. Lietuva stengèsi atgrasinti priešininkus remdamasi daugiausia nacionaliniais pajëgumais. Dabar Lietuvos atgrasinimo strategija apima ir trečiujų šalių saugumo garantijas, kurios strateginių studijų literatūroje įvardijamos išplèstinio atgrasinimo (ang. extended deterrence) sąvoka. Siame straipsnyje siekiama išsiaiškinti abiejų etapų Lietuvos atgrasinimo strategijos pagrindinius principus, jų stipriąsias ir silpnąsias puses, pateikti atgrasinimo efektyvumo stiprinimo būdus ir priemones. Šiame straipsnyje remiantis strategijos teorijos klasikų darbais ir empirinėmis studijomis bus ịvertinamas Lietuvos atgrasinimo potencialas panaudojant ne tik karines, bet ir ekonomines, politines ir kitas priemones. Ypatingas dèmesys bus skiriamas Lietuvos apginamumo studijoms, kuriomis remiantis galima nustatyti išplèstinio atgrasinimo Lietuvoje sẻkmės sąlygas.

Lietuvos atgrasinimo strategijos tyrimo metodika yra gana sudètinga. Karinè jẻga šiuolaikiniame pasaulyje dažniausiai naudojama kaip netiesioginio spaudimo ịrankis, dèl to, suskaičiuoti jos panaudojimo atvejus yra gana sunku. Didele dalis informacijos yra nevieša ir ja naudotis nèra galimybių. Strateginiuose dokumentuose ar aukštų politikų pasisakymuose retai atsispindi tikrasis grèsmių vertinimas ir supratimas. Karinis planavimas dažnai nesutampa su politiku grėsmių supratimu. Kariniai planuotojai visada planuoja blogiausiam, kokia neįikètina būtų grésmés tikimybẻ. Karo strategai visada planuoti mažiausiai 10 metu priekị, darydami prielaidą, kad grésmès gali pasikeisti.

Lietuvoje ir kitose valstybėse atliekamas grèsmių vertinimas nuolat keičiasi. Praèjusiame šimtmetyje dauguma grèsmių pasaulio saugumui - genocidas, terorizmas, branduolinè konfrontacija - užklupdavo karinius planuotojus netikètai, todèl niekas negali aiškiai pasakyti su kokiais pavojais Lietuva gali susidurti per artimiausią laiką. Prieš mažiau kaip dešimt metų Lietuvoje Lenkija buvo suvokiama kaip vienas pagrindinių galimu priešininkų. Dabar Lenkija yra vienas pagrindinių strateginių partnerių ir sajungininkè NATO ir Europos sajungoje. Neabejotina, kad po dešimties metu Lietuvos grèsmių supratimas gali visiškai skirtis nuo dabartinio. Dabar vis didesnę grèsmę Lietuvai kelia nevyriausybines organizacijos ar nevyriausybinès grupès, kurios negali būti susietos su kokia nors konkrečia valstybe. Atgrasinti teroristus yra gerokai sudėtingiau ir tradicinės karinès priemonès dažniausiai lieka bevertès. Naujos grèsmès gali atsirasti netikètai, todèl Lietuvos ir jos sajungininkių atgrasinimo strategija turi būti lanksti, kad galètų atsakyti ị įvairaus pobūdžio karinius ir nekarinius iššūkius.

Šiandien, nors oficialiai niekas negrasina Lietuvai, tačiau kaimyninėse valstybè vis pasitaiko nerimą keliančių tendenciju. Baltarusijos prezidentas dažnokai savo kalbose užsipuola NATO valstybes ir organizuoja parodomąsias pratybas prie jų teritorijos, kurie dažniausiai sutampa su Baltarusijos vidaus politiniais įvykiais arba NATO šaliu pratybomis. Pavyzdžiui, prieš pat $2001 \mathrm{~m}$. rinkimus Baltarusijoje įvyko pratybos Neman 2001, kuriama Baltarusijos ginkluotosios pajègos atrėmè Lietuvos ir Lenkijos ataką, vèliau perėmè į kontrpuo- 
limą ir drauge su Rusija užėmė dalį NATO šalių teritorijos. Pratybose Berezina 2002 Baltarusijos kariniai vienetai perëjo Berezinos upę ir puolẻ vakarų kryptimi $^{3}$. Dauguma šiu pratybų turëjo dvigubą scenariju - taikos palaikymo operacijas, skirtas viešajai nuomonei formuoti, ir realius karinius veiksmus, kuriais siekiama kaimynėms pademonstruoti Rusijos ir Baltarusijos karinę galia ir pasiųsti politinius signalus NATO valstybėms.

NATO strateginė koncepcija skelbia, kad aljansas nemato dešimties metu priekyje jokios tiesioginès karinės atakos galimybės savo narių teritorijon, tačiau atgrasinimas pasiliko vienu iš kertinių NATO strategijos elementu. NATO valstybių nuostata nekurti planų tradiciniam kariniam konfliktui atspindi realų pajègų santyki - NATO dabar yra galingiausias pasaulio karinis aljansas, o grẻsmiu pobūdis pasikeitė. Tačiau atgrasinimo logika išliko ta pati - jeigu daroma prielaida, kad valstybes ir nevyriausybines organizacijos yra racionalūs veikèjai, kurie skaičiuoja savo kaštus ir naudą, gautą iš savo veiksmu, tai ju elgesį galima veikti. Atgrasinimo teoretikų nuomone, ši prielaida tinka nagrinèjant ir teroristines organizacijas, nors savižudžių sprogdinimai iš pirmo žvilgsnio atrodo iracionalūs, tačiau teroristinių organizacijų tikslai, kokie jie bebūtu, visada yra aiškiai suformuluoti ir viešai deklaruojami. Taktiniu lygmeniu atliekami teroristiniai aktai beveik visada turi gana aiškiai strateginiu lygmeniu suformuluotus uždavinius ir suprantami kaip efektyvi priemone jiems pasiekti.

Šiame darbe bus naudojamas Barry Buzan ir Eric Herring požiūris į atgrasinimą kaip i grasinimą panaudoti karinę jègą siekiant neleisti kitam subjektui daryti tam tikrus veiksmus (ang. making of military threats to prevent another actor from taking particular action). Atgrasinimas apima tiek keršto, tiek gynybos elementą. Atgrasinimo strategija remiasi pagrindine prielaida, kad atgrasinimo efektyvumą lemia naudos ir kaštų santykis. Lietuva siekdama atgrasinti turètu siekti, kad jos suteikti kaštai priešininkui turètų būtų didesni už jo gautą naudą. Kaštai apimtų ginkluotuju pajègu padarytą žalą pasipriešinimo metu, kariuomenės išlaikymo užimtose teritorijose kaštus, nekarinėmis priemonėmis padarytus nuostolius. Juos gali suteikti tiek besiginančioji šalis, tiek tarptautinè bendruomenè ar sajungininkai. Agresijos nauda apimtų strateginių vietų kontrolę, materialinius išteklius, tarptautinį prestižą ir kitus. Labai dažnai politiniai lyderiai agresijos naudą vertina per valstybės vidaus stabilumo arba net valdančio elito sugebëjimo išsilaikyti valdžioje prizmę.

Siekiant suteikti nepriimtinus kaštus, Lietuva turi turèti pakankamai pajègumu pasipriešinti agresijai ir sugebèti įtikinti priešininką, kad tie pajėgumai bus panaudoti. Svarbiausia problema, kylanti atgrasinančiai valstybei - ką reiškia turèti „pakankamai“ pajëgumu, kokia jų išraiška skaičiais. Nors atgrasinimas yra labai subtilus psichologinis žaidimas, apimantis valstybių lyderius ir plačiają visuomenę, šiame straipsnyje bus pabandyta duoti preliminaru įvertinimą, ar Lietuva sugeba atgrasinti potencialius priešininkus. Šios analizès pagrindas - naudos ir kaštu, kaip dvieju pagrindinių atgrasinimo strategijos elementu, įvertinimas.

${ }^{3}$ Stratfor, "Russia: Hoping Military Exercises Speak Louder than Words to U.S“. $2005 \mathrm{~m}$ rugpjūčio $8 \mathrm{~d}$. http://www.stratfor.biz; Vaiceliunas A. „Lithuanian membership in NATO and the EU: a Secure Future", Canadian Forces College, 2004, http://198.231.69.12/papers/ nssc6/vaiceliunas.htm, 20050601. 


\section{Kariniai pajègumai - atgrasinimo strategijos pagrindas}

Sugebëjimas karinėmis ir nekarinėmis priemonėmis primesti priešininkui kaštus yra pagrindinis kiekvienos valstybès atgrasinimo strategijos elementas. Nors Lietuva nepriimtinus kaštus gali primesti įvairiais būdais, ji turi mažai galimybiu smogti priešininkui pati nesigindama. Svarbiausia, nors ir ne vienintelè, karinè priemoné - tai stipri gynyba. Stipri gynyba sustiprina atgrasinimo efektą, parodydama dar prieš konflikto pradžią potencialiems priešininkams, kokie nepriimtini kaštai jų laukia įsiveržus į šalį ${ }^{4}$. Stipri gynyba turi būti pagrịsta realiais pajègumais ir patikrinta pratybų metu. Pažadas pradėti karą, kai priešininkas stengsis primesti savo valią, gali būti sẻkmingai išpildytas tik jeigu yra paruošta karo vedimo strategija ${ }^{5}$. Dar geriau - jei ši strategija jau buvo sèkmingai panaudota praktikoje. Priešininkas turi ne tik žinoti apie Lietuvos pajėgumų egzistavimą, bet ir būti tikras, kad valstybei nepritrūks politinės valios juos panaudoti.

Strategijos teorija išskiria du pagrindinius būdus, kuriais valstybès gali primesti priešininkui nepriimtinus kaštus:

- keršijant priešininkui jo teritorijoje, tai yra, baudžiamoji akcija, atsakant i oponento ataką. Atgrasinimo kerštu (ang. punishment) šalininkai mano, kad svarbiau ne apsiginti nuo priešininko atakos, bet sunaikinti svarbiausius jo objektus - miestus, pramonès centrus ir t.t. Šiuo atveju, priešininkas žinodamas Lietuvos nusistatymą „,̌iauriai“ atkeršyti, nedrįstų atakuoti. Kariniame žodyne šis būdas vadinamas atpildo (ang. deterrence by retaliation) strategija ${ }^{6}$;

- kariaujant ir neleidžiant priešininkui pasiekti jo norimų tikslų - užimti ir kontroliuoti mūsų valstybės teritorijos. Tikslas yra sunaikinti priešininko karines pajėgas ar palaužti valią tęsti kovą. Marginot linija Prancūzijoje arba Mannerheimo linija Suomijoje yra strategijos pavyzdys, kai valstybės bande atgrasinti priešą parodydamos, jog turi pakankamai pajėgumų naikinti priešą savo šalies teritorijoje, bet ne už jos ribu. Šis būdas vadinamas atsaku (ang. deterrence by denial). Atsakas ir gynyba faktiškai turi identiškas reikšmes?

Lietuva gali naudoti abejus kaštų primetimo variantus, nors atgrasinimo kerštu strategijos taikymas Lietuvoje yra mažai tikètinas. Atgrasinimas kerštu reikalauja iš valstybès turèti pakankamai galimybių smogti priešininkui atgal ị jo teritoriją. Lietuvai igyvendinti toki grasinimą neturint masinio naikinimo ginklo yra gana sunku, be to jie yra uždrausti Lietuvos Respublikos Konstitucijoje. Konvencinès puolamosios ginkluotes kaštai kol kas viršija Lietuvos gynybos

${ }^{4}$ Buzan B., Herring E., The Arms Dynamic in World Politics, London: Lynne Rieners, 1998, p. 136.

${ }^{5}$ Osborne III G. K., The Nature of Deterrence. In J. Mearsheimer, ed., Conventional Deterrence, Toronto: Cornell University Press, 1985, p. 10.

${ }^{6}$ Pierce A. C. The Strategic Defense Initiative: European Perspectives. In C. Kelleher, G.Mattox, ed., Evolving European Defense Policines, Lexington books, 1987, p. 151.

${ }^{7}$ Buzan B., Herring E., (note 5), p. 135-136. 
biudžeto galimybes. Toliašaudė artilerija, sparnuotosios ar balistines raketos, bombonešiai, reaktyviniai lèktuvai, koviniai laivai nèra numatyti Seimui pateiktojoje ilgalaikèje Krašto apsaugos sistemos plètros programoje ${ }^{8}$. Turimi Lietuvos kariuomenès pajėgumai leidžia sẻkmingai veikti Lietuvos teritorijoje ar dalyvauti tarptautinėse taikos operacijose, tačiau atgrasinimo kerštu strategijai jie nẻra tinkami. Panaši situacija Latvijoje ir Estijoje.

Vienintelès karinio poveikio priemonès, kuriomis Baltijos valstybės gali grasinti priešininko teritorijai - tai sabotažo aktai, mažu specialiujų operaciju vienetu prasiskverbimas i priešininko teritoriją ar kiti asimetrinès kovos veiksmai. Tikriausiai vèliau didès pasiruošimo įvykdyti informacinę ataką reikšmė, priešo karinių kompiuterinių tinklų suardymas, ryšiu sistemų trukdymas, valdymo ir vadovavimo sistemos griovimas gali prisidèti prie efektyvaus atgrasinimo užtikrinimo. Pagrindinè šių priemonių silpnybè - turimų priemonių atskleidimas leistų priešininkui sukurti efektyvią gynybinę strategiją, o jų slėpimas neturètu jokio psichologinio priešininko sprendimo prièmimo procesui. Po narystės NATO tapo galimas kitas atgrasinimo kerštu būdas - kariniai ir nekariniai sajungininkų veiksmai potencialaus agresoriaus atžvilgiu. Apie tai plačiau bus diskutuojama pristatant Lietuvos gynybos scenarijus.

Puolamosios ginkluotès stoka ir silpni asimetrinio karo vedimo priešininko teritorijoje pajegumai paaiškina tai, kad iki kolektyvinès gynybos garantijų Lietuvos atgrasinimo efektyvumas rèmėsi tik savo pačios gynybine galia, tai yra galimybe užtikrinti ir vykdyti gynybą (atsaką) Lietuvos teritorijoje. Pagrindinis tikslas - padaryti priešininkui didesnių nuostoliu, nei jis gaus naudos savo veiksmų Lietuvos atžvilgiu, būtų igyvendinamas kariaujant tikrą karą. Tokia strategija rèmėsi keletu pagrindinių prielaidų. Lietuvos politikai ir kariniai planuotojai manè, kad:

- Lietuva yra per maža, kad galètų tikètis laimèti konvencinį karą prieš daug galingesni priešininką;

- Lietuvos ginkluotosios pajėgos, nors ir mažesnės už priešininkus, sugebės tam tikrą laiko tarpą stabdyti priešininką, neleis jam kontroliuoti šalies teritorijos ir greitai sukurti okupacinių struktūrų;

- Lietuvos gyventojai priešinsis agresoriui visomis įmanomomis priemonėmis, o kolaborantų skaičius bus labai mažas;

- Lietuvos gyventojų karinis pasipriešinimas truks bent keletą metu, o gal ir keletą dešimtmečių;

- Užsienio valstybės reikš paramą Lietuvai, tačiau tai bus politinė, galbūt ekonominè, bet ne karinè pagalba.

Šios prielaidos atsispindèjo oficialiosios Lietuvos dokumentuose ir rengiamuose gynybos planuose. 2000 metu palio mèn. priimtos Lietuvos karinès gynybos strategijos skyrius „Atgrasinimas“ skelbe, kad jog Lietuvos atgrasinimo strategija rèmèsi nuostata, kad:

užpuolimo atveju Lietuva ginsis, nepaisydama agresijos pobūdžio ar puolančiu pajègų dydžio ir nepriklausomai nuo to, ar bus ir kada bus suteikta tarp-

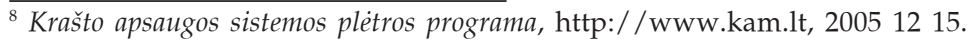


tautinė pagalba. Ginkluoto užpuolimo atveju Lietuva neleis priešininkui pasiekti savo tikslu - efektyviai kontroliuoti valstybès teritorijos, laisvai naudotis jos infrastruktūra bei ištekliais ir kurti okupacinių tarnybų

Lietuvos atgrasinimo strategija rèmėsi tuo, kad įtikintų potencialius priešininkus, jog jiems nepavyks laisvai užimti ir kontroliuoti šalies teritorijos. Karinè okupacija pareikalautų didžiulių lèšu, tuo labiau, kad, tuometinių strategu matymu, Lietuvos gyventojų pasipriešinimas tęstųsi ne vienerius metus. 1999 metais padarytoje neoficialioje Krašto apsaugos ministerijos studijoje minama, preliminariais skaičiavimais, išlaikyti užsienio 40 tūkst. žmonių korpusą vienerius metus Lietuvos teritorijoje turètų kainuoti $0,8 \mathrm{mlrd}$. JAV doleriu, o visų Baltijos šalių verte turètų pasiekti 1,5 mlrd. JAV dolerių ${ }^{10}$. Žinant, kad tokie kaštai lauktų dešimt metu, o gal ir ilgesnį laikotarpí, Lietuvos okupacija turètų neatrodyti labai viliojanti alternatyva. Neoficialios studijos autoriai siūlè atsižvelgti ir i ekonominių sankciju, kurių kaštai būtų daug didesni nei kariuomenės okupuotose šalyse išlaikymas, dydị.

Lietuvos karo planuotojai rèmėsi savo vertinimu, kad Lietuva ir kitos Baltijos šalys kariniu strateginiu požiūriu yra labiau svarbios regioniniu, o ne globaliu mastu. Todẻl nei viena didelè valstybès neaukotų didžiulių išteklių vien Lietuvos teritorijai užimti, tuo rizikuodama įsivelti į didesnio pobūdžio krizę. Lietuva vertinga tik kaip placdarmas kitiems tikslams pasiekti, todèl tiktai totalinės konfrontacijos tarp Rytų ir Vakarų atveju, dèl savo geostrateginės padėties ypatumu, Lietuva galètų atsidurti pagrindinio smūgio zonoje. Lietuvos kariniai planuotojai visiškai teisingai manè, kad karinio konflikto regione atveju:

- potencialus agresorius greičiausiai ryšis naudoti ne visus, bet tam tikrą dalį savo ištekliu, sieks tik ribotų tikslų, o ne visos valstybės okupacijos ir stengsis nepatirti dideliu nuostoliu, arba;

- konfliktas bus globalus, o potencialaus agresoriaus veiksmai Lietuvos atžvilgiu bus nulemti bendros Rytų - Vakarų karinès pusiausvyros. Tokiu atveju Lietuvos kariniai pajėgumai neturi didelès reikšmès.

Lietuvos karo planuotojai darè išvadą, kad antro varianto tikimybẻ labai maža, todèl Lietuva turi daugiausia pastangu skirti atgrasinti agresiją su ribotais tikslais. Šiuo atveju Lietuvos karinė atgrasinimo strategija turètų siekti suteikti priešininkui didžiulius kaštus ir neleisti kontroliuoti Lietuvos teritorijos. Karinių strategų manymu, puolimui reikalingos daug didesnès pajėgos nei gynybai, todèl atgrasinantysis turi turèti mažiausiai vieną trečdalį atgrasinamojo karinės galios. Svarbiausias faktorius yra ne absoliuti galia, bet pajėgumų santykis (proporcija) tam tikrame atakos taške ${ }^{11}$. Toks kariuomenès dydis igalintu stabdyti priešininką ir neleistų įsiveržti į krašto gilumą, o tai suteiktų laiko vykdyti mobilizaciją ir pakeistų puolimo - gynybos santykị Lietuvos naudai.

\footnotetext{
${ }^{9}$ Lietuvos karinés gynybos strategija, (nuoroda 2), p. 9-10.

${ }^{10}$ Atgrasinimo strategija II, Krašto apsaugos ministerija, 1999.

${ }^{11}$ Encyclopeadia Britannica. „The Theory and Conduct of War. Conventional Strategy", http:/

/www.britannica.com/, 20050228.
} 
Lietuvos karo planuotojai suprato, kad potencialus agresorius gali surizikuoti ir žaibiškai užimti teritoriją prieš įsikišant bet kokiai išorinei jẻgai, bei laikyti iškovotas pozicijas tol, kol pasieks savo politinius tikslus. Kitais žodžiais, jo tikslas būtu iš pradžiu laimèti kara, o paskui laimèti ir taiką. Agresoriaus planai gali ir žlugti, bet tai jau nebesvarbu atgrasinimui ${ }^{12}$. Todèl reikalingos sugebančios greitai reaguoti pajejgos, galinčios stabdyti priešininką nuo pat konflikto pradžios ir sugebančios apsaugoti strateginius šalies objektus nuo priešininko ataku.

Lietuvos kariuomenés plètros planai atitiko šiuos apskaičiavimus. Pagal $1998 \mathrm{~m}$. patvirtintus planus, $2008 \mathrm{~m}$. Lietuvos kariuomenès personalas turëjo pasiekti 23 tūkstančius, o dar vèliau - net 48 tūkstančius karių. $2000 \mathrm{~m}$. Lietuvos karinės gynybos strategija skelbė, kad Lietuvos kariuomenės:

reguliariosios sausumos pajejgos, karo metu sustiprintos rezervo vienetais, sudaro pagrindinę karinės gynybos jègą. Joms skiriamas pagrindinis vaidmuo ịgyvendinant karinëje strategijoje numatytus uždavinius. Reguliariosios sausumos pajègos plètojamos iki keturių kovinių ir vienos logistikos brigadu. Viena iš keturių kovinių brigadų bus parengta kaip greitojo reagavimo brigada. Kiekviena kovinè reguliariujų sausumos pajėgų brigada paprastai bus sudaryta iš trijų motorizuotujų ar mechanizuotujų péstininkų batalionų ir paramos vienetų. Logistikos brigadą sudarys transporto, tiekimo, remonto ir medicinos batalionai ${ }^{13}$.

Papildomai, Lietuva turèto paruošti apie 100 tūkst. aktyviojo rezervo karių, kurie konflikto metu papildytų reguliariąsias pajègas. Šimtatūkstantinė Lietuvos kariuomene papildyta viešosios policijos, pasienio apsaugos, Šaulių sąjungos vienetais ir palaikoma gyventojų būtu grèsminga jèga, galinti palaidoti bet kokio agresoriaus viltis greitai užtikrinti okupuotos teritorijos kontrolę.

Lietuvos atgrasinimo strategijoje svarbus buvo rizikos elementas. Lietuva planavo, kad agresoriu gali sulaikyti ne tik nepriimtinų kaštų suteikimas, bet nesugebejimas jų apskaičiuoti, kylantis dèl konflikto metu tvyrančio chaoso. Empirinès studijos aiškiai rodo, kad agresoriams trumpi karai yra labiau pakenčiami nei ilgi, nes ju kaštai yra žymiai mažesni. Dažniausiai priešininkai renkasi tą alternatyvą, kurios scenarijus yra daugiau mažiau aiškus, ir būsimi įvykiai yra prognozuojami. Kadangi ilgas karas yra rizikingas, jie jo nepradės, jeigu nebus užtikrinti dèl greitos pergalès. Jei pergalẻ yra neužtikrinta ar nusimato tik po ilgo ir sekinančio konflikto, atgrasinimo sẻkmės šansai labai padidèja ${ }^{14}$. Nesugebejjimas apskaičiuoti kaštus yra beveik pakankama sąlyga tam, kad atgrasinimas suveiktų. Būtent to ir sieké Lietuvos kariniai planuotojai.

Lietuva siekè įtikinti bet kurị potencialų priešininką, kad jis nesugebès pasiekti greitą pergalę ir kontroliuoti paskui seksiančiu ịvykių eigą. Lietuva

\footnotetext{
${ }^{12}$ Gray C. „Deterrence and Regional Conflict: Hopes, Fallacies, and „Fixes", Comparative Strategy 17 (2), 1998, p. 58.

${ }^{13}$ Lietuvos karinės gynybos strategija, (nuoroda 2), p. 20.

${ }^{14}$ Plačiau apie šia teoriją Rhodes E. Review of Empirical Studies of Conventional Deterrence.

Occasional Paper, Center for Global Security and Democracy, Rutgers University, 1999, http:/

/www.ciaonet.org, 20050601.
} 
grasino potencialiems agresoriams ilgu partizaniniu karu, kuris pagal apibrèžimą, suteikia mažiau galimybių apskaičiuoti kaštus ir juos kontroliuoti, tai yra, jis sukuria neapibrèžtumo situaciją. Šioje strategijoje ypatingai svarbus buvo krašto apsaugos savanoriu (teritorinès kariuomenès) vaidmuo. Nors ginkluoti tik lengvaja šaulio ginkluote savanoriai negalëjo kovoti moderniame mūšio lauke, jiems buvo skirta kita funkcija - reguliarioms pajėgoms stabdant priešo slinkimą, pamažu pereiti į partizaninį karą. Buvo manoma, kad dešimtys tūkstančiu gerai apmokytų savanorių neleistu priešininkui naudotis Lietuvos infrastruktūra, kontroliuoti tranzitinius kelius ar pramonės objektus.

Visuotine gynyba grindžiama Lietuvos atgrasinimo strategija pasižymèjo puikia logika ir pagrịstomis prielaidomis, nors ir turèjo nemažai silpnybių. Visu pirma, norint sėkmingai atgrasinti vien tik turèti pakankamai gynybiniu pajëgumu neužtenka - jei priešininkas apie juos nežinos, jis elgsis taip, tarsi ju iš viso nebūtų. Konvencinis atgrasinimas susijęs su informacijos kaip aš tave nubausiu kuo detalesniu perdavimu, todèl priešininkas turètų būti informuojamas apie turimus pajègumus - ginkluotę, mobilizacinį rezervą, personalo skaičių ir kitą kritinę informacija. Priešininkams taip pat reikètų parodyti, kad šie pajëgumai yra tikrai veiksmingi. Geriausia tai padaryti didelių pratybu metu, i kurias reikètu, siekiant ịtikinti priešininką savo karine galia, pakviesti ir visu suinteresuotų šaliu stebėtojus. Toks atvirumas leistų visiems nuspèti Lietuvos gynybos planus ir adaptuoti pagal tai savo strategiją. "Gynejjas yra prieš dilemą - noredamas atgrasinti jis turi atrodyti pranašesniu, galinčiu padaryti žalą. Bet norèdamas būti pranašesniu, jis turi savo galimybes laikyti paslaptyje ${ }^{15 “}$. Šiuo atveju, Lietuvos atgrasinimo logika gerokai susilpnètu. Tuo tarpu agresorius neturi perdavinèti jokios informacijos apie savo ketinimus ir pajegumus.

Antra, tokia strategija yra labai brangi. Visuotinės gynybos koncepcija reikalauja didžiulių išlaidų personalui parengti (šimtai tūkstančių rezervistų ir krašto apsaugos savanoriu), dideliu ginkluotės atsargu, visos valstybės mobilizacinės sistemos sukūrimo. Popieriuje tokia strategija lyg ir atrodè paremta realiais ištekliai1999 m. sausio 14 d. Lietuvos Respublikos Seimas prièmė Krašto apsaugos sistemos finansavimo strategijos įstatymą, kuris nustatẻ krašto apsaugos sistemos finansavimo pagal programas santykinius rodiklius ${ }^{16}: 2000 \mathrm{~m} .-1,70-1,75$ proc. bendrojo vidaus produkto, 2001 m. - 1,95-2,00 proc. bendrojo vidaus produkto. Krašto apsaugos ministerija planavo, kad vèliau išlaidos kariuomenei padidès net iki 2,25 procento bendrojo vidaus produkto. Šie planai niekada nebuvo igyvendinti, o krašto apsaugos finansavimas beveik niekada nesiekè 1,5 proc. bendrojo vidaus produkto. Lietuvos visuotinès gynybos sistema, nors ir buvo pradèta kurti, tačiau niekada nepasiekėSuomijos, Švedijos ar Šveicarijos turimų pajėgumų. Ji netgi niekada nebuvo patikrinta praktiškai, kadangi Lietuvos įstatymai numate tik visuotinę mobilizaciją, tuo tarpu pabandyti mobilizuoti kurị nors Lietuvos rajoną ar vietovę nebuvo galimybių. Todèl tiek Lietuvos politikai, tiek potencialūs agresoriai taip ir nesužinojo visų Lietuvos pajègumų pasipriešinti agresijai.

15 Ten pat.

${ }^{16}$ Lietuvos Respublikos krašto apsaugos sistemos finansavimo strategijos įstatymas, $1999 \mathrm{~m}$. sausio 14 d. Nr. VIII-1028, http://www3.lrs.lt/cgi-bin/preps2?Condition1=71537\&Condition $2=$. 
Trečia, narystė NATO ir ES leido užtikrinti patikimą atgrasinimą kitais, ne mažiau efektyviais būdais. Jeigu anksčiau sajungininkès ruošèsi atremti išorines grèsmes savo teritorijoje, tai $1999 \mathrm{~m}$. NATO strateginëje koncepcijoje kolektyvinė gynyba buvo papildyta prevencijos elementais. Naujoms grèsmėms valdyti ir atremti reikia santykinai mažesniu, tačiau geriau apmokytu, mobilesniu, greičiau reaguojančių pajėgu, gebančių sklandžiai veikti išvien tiek su daugianacionaliniais junginiais tarptautinėse operacijose pajègų. Aljanso kuriamos greito reagavimo mobilios ekspedicinės pajėgos, galinčios preventyviai grẻsmes stabdyti ju kilimo vietoje gali atlikti ir teritorinės gynybos užduotis, tačiau teritorinei gynybai parengtos pajègos negali vykdyti kolektyvinès gynybos ir prevencijos uždavinių. Toliau plètojant teritorines pajėgas susidarytu , free rider" efektas - šalis naudotųsi 5 straipsnio garantijomis, tačiau nesukurtų jokios pridėtinės vertės Aljansui.

Lietuva, kaip ir kitos sajungininkės, negali išlaikyti totalinei gynybai skirtos didelės šauktiniais paremtos reguliariosios kariuomenès bei didelio rezervo ir kartu kurti kolektyvinei gynybai reikalingus pajėgumus. Lietuva kaip NATO nare paskelbė gynybos planavime teiksianti prioritetą tiems pajègumams, kurie stiprins viso Aljanso kolektyvinę gynybą. Lietuvos kariuomenè turès būti mobili ir lanksti, o tam reikès tinkamai parengto personalo, modernios ginkluotès, technikos ir įrangos, tinkamos vadovavimo ir valdymo bei kovinio rengimo sistemos. 2006 - 2011 m. krašto apsaugos ministro gairèse pasakyta, kad reikia atsisakyti tų karinių vienetų bei pajègumu, kurie skirti vien teritorinei gynybai, yra neefektyvūs, negali veikti daugianacionalinių pajėgų sudètyje bei vykdyti kolektyvinès gynybos ịsipareigojimu ${ }^{17}$. Naujos planavimo kryptis keičia Lietuvos atgrasinimo strategijos kryptis nuo atgrasinimo atsaku link kolektyvinio atgrasinimo, kuriame dominuoja prevencijos elementai.

\section{Kariniai pajègumai reikalingi išplèstiniam atgrasinimui}

Po narystės NATO Lietuvos atgrasinimo strategija iggavo naujų bruožų. Atgrasinimo strategijos principai išliko tie patys, o karinis šalies pajėgumas išliko svarbiu veiksniu, garantuojančiu patikimą šalies gynybą ir atgrasinimo efektyvumą. Tačiau po narystės Aljanse, karinės priemonès apima ne tik Lietuvos nacionalinius pajègumus, bet ir sajungininku galimybes primesti nepriimtinus kaštus potencialiems agresoriams. NATO ir Europos Sajunga turi didžiuli potencialą, kuris gali būti panaudotas taikant karines, ekonomines ir kitas priemones priešiškai nusiteikusioms valstybėms ar netgi nevalstybiniams veikëjams.

Svarbiausias iššūkis Lietuvos sajungininkų teikiamam išplèstiniam atgrasinimui - suteikiamu garantijų patikimumas. Iૃtikinti agresoriu, kad silpnesnė valstybė naudos karinę jẻgą savigynai sunku, tačiau įmanoma. İtikinti agresorių, kad valstybè naudos karinęjègą kitos valstybės gynybai, yra žymiai sudè-

${ }_{17}$ Krašto apsaugos ministro gairés 2006-2011 m., Vilnius, KAM Leidybos ir informacinio aprūpinimo tarnyba, 2004, p. 10 
tingiau. Sunkumai užtikrinant patikimą atgrasinimą NATO šalyse dažnai kẻlė abejones dèl sajungininku gebëjimo prisiimti ịsipareigojimus Baltijos šalims. Politikai sutikdavo, kad saugumo garantijos turi būti tvirtos ir patikimos. Aljanso šalyse vyravo nuomonè - jeigu kitoms šalims kyla rimtų abejonių dèl NATO galimybių užtikrinti Baltijos šaliu gynybą, tai geriau jų iš viso nesuteikinèti. Nepatikimos garantijos nepadidintų Baltijos šalių saugumo ir sukeltų abejoniu NATO įsipareigojimais kitų šalių atžvilgiu.

NATO turi didžiulį karinės galios pranašumą prieš bet kurią pasaulio valstybę, tačiau tam tikrame pasaulio taške, pavyzdžiui, Baltijos regione, šis pranašumas nèra toks akivaizdus. Kariniai strategai visada turi atsižvelgti i blogiausią scenariju - Rusija tampa JAV priešininke ir jèga grasina Baltijos valstybėms. Pavyzdžiui, pagal Rusijos generalinio štabo planus dẻl karinès strateginès svarbos Baltijos šalys būtų okupuojamos pačioje karo pradžioje ${ }^{18} .1999 \mathrm{~m}$. Rusijoje prasidëjo karinè reforma, kurios tikslas - padaryti karines pajejgas veiksmingesnes, ypatingą dèmesį skiriant greito reagavimo daliniams. Reformuojant pirmumas teikiamas dviem kryptims: Vakarams (iskaitant Kaliningrado sritį) ir Uralui. Kaliningrado srityje nuo dviejų divizijų pereinama prie greito reagavimo brigadų. Karių skaičius sumažejo nedaug, ir tai daugiausia mažinant vadaviečiu personalą. Baltarusijoje reformos prasidejjo iškart po pratybų „Neman 2001“. Baltarusija padalyta į du regionus „Vakarai“ ir "Šiaurès Vakarai“ kiekviename sukuriant po tris greitojo reagavimo brigadas. Reformuojant Baltijos valstybių kaimynystëje bus sukurtos mažesnès, tačiau galingesnès karinės pajẻgos $^{19}$. Todèl patikimos NATO saugumo garantijos reiškia, kad sajungininkai bet kokiam scenarijui turi pajejgumų užtikrinti Baltijos šalių gynybą.

Neatsitiktinai, dar $2001 \mathrm{~m}$. pradžioje dèl sajungininkių nesugebëjimo užtikrinti patikimą atgrasinimą ir gynyba daugelyje šalių vyravo ịsitikinimas, kad Lietuva nebus pakviesta į antraji NATO plètros etapą. Śtai $2001 \mathrm{~m}$. balandžio 30 d. įtakingas JAV strateginių studiju centras Stratfor paskelbẻ analizę „Baltic States Membership in NATO Unlikely“. Stratfor nuomone:

apginti ir siųsti pastiprinimą i Baltijos šalis yra sunku dèl ilgos fronto linijos, mažo gynybos gylio ir ribotu galimybių perkelti pastiprinimą karo metu. Konflikto atveju dèl Rusijos noro žūtbūt apginti Kaliningrado sritį ir joje esančius uostus Baltijos šalims reikès pastiprinimo iš Aljanso teritorijos. NATO turès siųsti pagalbą sausuma, nes dislokuota Kaliningrade Rusijos kariuomenė neleis tai padaryti oro ar jūrų keliu. Sausumos kelių infrastruktūra, sukurta Maskvos valdymo metais, yra palankesnė Rusijai. Sunkumai perkelti pastiprinimą į Baltijos šalis leis Rusijai jị lengvai neutralizuoti paliekant NATO karius laukti pagalbos kur nors ant Baltijos jūros kranto ${ }^{20}$.

Stratfor manymu, dèl savo pažeidžiamumo bet kokios NATO saugumo garantijos būtų tik popieriaus lapas. Geriausiu atveju NATO gali pasiūlyti strateginį atgra-

${ }^{18}$ National Defense University "Strategic Assessment: Flashpoint and Force Structure“, 1997, http://www.ndu.edu/inss/sa97/sa97ch2.html, 20020601.

${ }^{19}$ Полевой А. „В Белоруссии реформируют армию“, Независимая Газета, 2001 m. spalio 25 d.

${ }^{20}$ Stratfor, "Baltic States Membership in NATO Unlikely“. $2001 \mathrm{~m}$. balandžio $30 \mathrm{~d}$. http:// www.stratfor.biz, 20030901. 
sinimą - pakišti Baltijos šalis poJAV branduoliniu skèčiu, bet mažai vilčiu, kad Rusija tikès JAV noru rizikuoti branduoline konfrontacija dèl Baltijos valstybių ${ }^{21}$.

Detalesnę teoriškai numanomos konfliktinės padèties studiją (,,Strategic and Operational Implications of NATO Enlargement in the Baltic Region") paskelbe JAV užsienio politikos analizès institutas. Jos išvadose rašoma, kad, nepaisant visų politiniu pokyčiu, Rusija ilgai turi būti nagrinejjama kaip pagrindinė grèsmé Baltijos regiono saugumui. Studijos autorių nuomone, blogiausiu atveju būtų vykdoma tokia operacija kaip, pavyzdžiui, Persijos įlankoje ir naudojami panašūs pajėgumai. Tai apimtų strateginį pervežimą, greitą reagavimą ir specialiuju pajègų dislokavimą, galimybę pradinėse konflikto stadijose kontroliuoti oro erdvę ir vykdyti operacijas prieš Rusijos povandeninius laivus ${ }^{22}$. Autoriu nuomone, JAV tektu pagrindinė našta, ginant Baltijos šalis, nes ji užtikrintu dominavimą ore ir dislokuotų specialiąsias pajėgas. Konflikto atveju JAV sugebėtų užtikrinti tokią paramą Baltijos šalims, tačiau problemų galètų kilti, jei JAV tuo metu dalyvautų kitame konflikte, pavyzdžiui, Persijos įlankoje, Šiaurès Rytų Azijoje ar pietiniame Aljanso sparne. Studijos autorių nuomone, jei Rusija per konfliktą panaudotu tik įprastinę ginkluotę, apginti Baltijos šalis nebūtų ypač sunku. Tačiau, teigia jie, „mūsų vertinimu, Baltijos valstybėms priešiškai nusiteikęs režimas puldamas greičiausiai neapsiribos tik įprastomis priemonemis. Todèl tiek sajungininku, tiek Baltijos gynybos planuotojai neturètu atmesti varianto, jog Rusija nenaudos masinio naikinimo ginklo tik todèl, kad tai pažeistu tarptautinės teisės normas ar dar labiau išplėstų konfliktą “23.

Studijos autorių teigimu, tokio konflikto tikimybẻ labai maža, todèl Amerikai Lietuvos ir kitų Baltijos valstybiu prièmimo nauda yra daug didesnẻ už galimą kainą, net jei išsipildytu pačios blogiausios prognozės.

Artėjant narystei NATO, Baltijos šaliu gynybos galimybės buvo vis plačiau diskutuojamos oficialiuose ir akademiniuose sluoksniuose. Vienas svarbiausių pasisakymų šia tema buvo raštiškas RAND korporacijos analitiko Stephen Larrabbee kalbos JAV Senato debatuose dèl NATO plètros tekstas ${ }^{24}$. Jame ir neoficialiose diskusijose dažniausiai prieinama prie išvados, kad agresijos atveju Lietuva gali būti ginama keliais būdais. Pirma, svarstomas lenkiškas variantas, kai ginamasi naudojant daug ịprastinès ginkluotės (tanku, artilerijos, šarvuotų péstininkų mašinu, puolamujjų sraigtasparnių, naikintuvų). Šitaip ginantis norima atremti priešininko ataką kovos lauke. Antra, ginantis naudojant "technologinį" modeli, NATO parama ateina iš JAV, daugiausia tolimojo nuotolio pajègomis (smūgiuojama panaudojant tolimojo nuotolio raketas, strateginius bombonešius). Mažai pasikliaujama ịprastine ginkluote ir pastiprinimu iš

\footnotetext{
${ }^{21}$ Stratfor, "Faceoff in the Baltics NATO Expands the West-Russia Confrontation". $2000 \mathrm{~m}$. kovo 3 d., http://www.stratfor.biz, 20030901.

${ }^{22}$ Institute for Foreign Policy Analysis (IFPA) „Strategic and Operational Implications of NATO Enlargement in the Baltic Region“, 2002, p. 3.

${ }^{23}$ Ten pat.

${ }^{24}$ Larrabee S. "The Baltic States and the NATO Membership“. Testimony of Dr. S. Larrabee, RAND, before US Senate Foreign Relations Committee, 2003 m. balandžio 3 d. http:// www.rand.org/publications/CT/, 200309 01. Taip pat Larrabbee S. NATO's Eastern Agenda in a New Strategic Era, Santa Monika: RAND, 2003, p. 62-64.
} 
Europos. Trečias yra mišrus variantas. Šiuo atveju remiamasi tiek ịprastomis pajègomis, tiek smūgiais iš toli. Paskutinis ir tik teoriškai egzistuojantis modelis yra atgrasinimas kerštu. Šiuo atveju būtų suduodami tolimojo nuotolio smūgiai, bet pasirenkami ne kariniai, o civiliniai ir ekonominiai taikiniai agresoriaus teritorijoje. Veikiausiai būtų naudojami masinio naikinimo ginklai.

Sie skirtingi variantai įvairiai palaikomi tiek JAV, tiek jos sajungininkiu, tiek naujujų NATO narių. Visų pirma akivaizdu, kad Šaltojo karo laikų abipusio sunaikinimo koncepcija grịstas paskutinis variantas turi mažiausiai šalininku tiek JAV, tiek Europoje, tiek Baltijos šalyse. JAV lengviausia užtikrinti „technologinį" modelį, kuris finansiškai būtu pats pigiausias ir remiasi jau dabar JAV turimais pajègumais. Toks variantas nesusilauktų Baltijos šalių paramos, nes tuo atveju JAV lieka tik politiškai įsipareigojusi ginti jų nepriklausomybę ir kilus konfliktui potencialus agresorius gali suabejoti JAV įsipareigojimais ginti Baltijos šalis. Europos valstybės, NATO narès, aiškiai pritartų tradiciniam lenkiškam variantui. Tai reikalautų iš Baltijos valstybių kurti dideles, teritorinès gynybos veiksmu galinčias imtis pajègas, kurios vargiai galètu prisidèti prie būsimu, toli nuo regiono vykdomu Aljanso operaciju. Atsižvelgiant į tai, kad NATO siekia mažu, mobilių ir greitai dislokuojamų pajẻgu, toks variantas sunkiai įmanomas. Baltijos šaliu gynybai kaip Baltijos šalių poreikių ir sajungininkiu galimybių kompromisas optimaliausias yra mišrus variantas. Jis reiškia, kad konflikto atveju įvairus pastiprinimas ateis tiek iš kaimyniu, tiek iš JAV. Mišrus variantas garantuoja, kad atgrasinimas grindžiamas tiek karo neišvengiamumu, tiek kerštu. Baltijos valstybėms jis reiškia, kad juntamas NATO sajungininkių buvimas regione, ir tai smarkiai padidina atgrasinimo veiksmingumą. Siuo atveju Lietuva, kaip ir kitos Baltijos valstybès, yra suinteresuotos ne tik politiniais įsipareigojimais, bet ir jų kariniu buvimu regione, pavyzdžiui, išlaikant NATO oro policijos misiją, vykdomą iš Zokniu aviacijos bazès Šiauliuose.

RAND atlikta analizè išsklaidè daugelio NATO valstybiu abejones dèl Baltijos šalių apginamumo. Dar detalesnè analizè buvo pateikta $2004 \mathrm{~m}$. RAND korporacijos studijoje "Assuring Access in Key Strategic Regions“ ${ }^{425}$. Tai nèra oficialus dokumentas, tačiau atliktas JAV valstybiniu institucijų užsakymu, o jo parengime dalyvavo žinomi kariniai strategai, kurie atsakingi už konkrečiu gynybos planų rengimą. Scenarijus remiasi JAV-Rusijos santykių paaštrëjimu. Rusijos įnirši bei griežtą laikyseną apspręs NATO priartejjimas prie Rusijos sienu Rytų ir Vidurio Europoje bei JAV bazių buvimas Vidurinèje Azijoje, tradiciniuose Rusijos įtakos regionuose. Jausdamasi vis labiau pažeidžiama, Rusija bei jos politinè ir karinè vadovybẻ nesusitaikytų su mintimi, kad Baltijos šalių narystė NATO yra negrįžtamas procesas ir kad Rusijos įtaka šiose valstybėse galutinai prarasta. Savo ruožtu JAV reikštų nepasitenkinimą dèl tebesitęsiančių glaudžiu Rusijos ir Irano santykių ir Rusiją vis labiau laikytų „blogio ašies“ šalimi nei patikima ir atsakinga sajungininke. Nei viena pusė nebūtų linkusi nusileisti, išaugtų karinio susidūrimo Baltijos valstybėse grèsmè.

${ }^{25}$ Larson E. V., Eaton D., Elrickn P., etc. Assuring Access in Key Strategic Regions. Santa Monica: RAND, 2004, p. 65-86; Larrabee S. ten pat.; Taip pat "Galimi kariniai NATO susidūrimai 2003-2012 m.", Tèvynès sajunga, 200410 04, http://www.seimas4.1t/article.php?id_art=5014, 20050601. 
Baltijos scenarijuje nurodoma, kad Rusija karinėmis priemonėmis stengtųsi atkirsti Lietuvą, Latviją ir Estiją nuo NATO. Numanomos krizės Baltijos valstybėse priežastimi esą taptų Estijos ir Latvijos nesugebẻjimas galutinai integruoti rusakalbiu šiu šaliu piliečių. Rusų nuomone, jiems nebūtų suteiktos visos pilietinès teisės ir tokiu būdu jie būtų diskriminuojami. Dèl to gali vis labiau stiprèti rusų reikalavimai tų šalių vyriausybėms, prasidètų protesto akcijos dèl pilietinių teisiu suteikimo. Kartu būtu ieškoma Rusijos pagalbos. Tai padètų Rusijos žvalgybai išnaudoti esamą nepasitenkinimą, ji dar labiau sustiprintų teikiant finansinę bei organizacinę paramą. Krizei stiprëjant, radikaliausiai nusiteikusios rusų grupuotės šturmuotų vyriausybių įstaigas. Kiltų susidūrimai su tụ valstybių saugumo pajègomis. Tai suteiktų galimybę Rusijai bandyti įkalti pleištą tarp Baltijos valstybių ir NATO bei pasiekti šios organizacijos sprendimų vilkinimo.

Numatydama netikèto ir greito karinio puolimo sẻkmę bei NATO pajėgu nesugebẻjimą greitai mobilizuotis, Rusija tokiu būdu tikètųsi užimti geras pozicijas tolesnèms deryboms. Galutinis tokio puolimo tikslas būtų „finliandizuoti“ Baltijos valstybes, atkirsti jas nuo NATO, tokiu būdu atgaunant jose įtaką bei sukuriant buferinę zoną tarp Rusijos ir NATO. Scenarijus numato, kad Rusija sẻkmingai bendradarbiautų su Baltarusija, o ši suteiktų ribotą paramą užimant Baltijos valstybes. RAND manymu, Rusijos operacinis planas remtusi keturiomis prielaidomis.

Pirma, Rusijai reikia bent 30 dienų mobilizacijai, tik tokiu atveju ji gali pasiekti savo strateginius tikslus regione. Todèl per pirmajį mènesi jinai negalètų vykdyti puolamuju operacijų. Antra, Rusijai reikia izoliuoti Baltijos šalis nuo atvykstančios NATO paramos. Trečia, Baltijos šalys turi būti užimtos greitai, taip sukuriant fait accompli situaciją ir užsitikrinant geresnes pozicijas vèliau prasidėsiančiose derybose. Ketvirta, Rusija turètų būti pasiruošusi atremti NATO kontrpuolimą. Rusijos desantinės pajėgos turi sugebèti išlaikyti Latvijos ir Estijos sostines ir dalį pajūrio zonos. Rusijos pajègos susidètų iš dviejų oro desantinių diviziju, triju motorizuotų šauliu pulku, dvieju tankų diviziju, specialiuju pajègu brigados ir triju priešraketinès gynybos brigadų. Dauguma pajègu priklausytu Leningrado karinei apygardai, kuri yra viena geriausiai aprūpintu visoje Rusijoje. Rusija panaudotų 200 kovinių lèktuvu, 100 bombonešiu, 50 kovinių sraigtasparnių ir daugybę pagalbinių lèktuvų. Labai svarbūs būtų Rusijos jūru pajègu pajėgumai, pavyzdžiui, dyzeliniai povandeniniai laivai arba laivai, ginkluoti tolimo nuotolio torpedomis, kuriais būtų siekiama sutrukdyti NATO prièjimą prie Baltijos šaliu jūros keliais. Rusijos integruota oro gynybos sistema ginkluota dešimtimis ilgo nuotolio raketomis žemè - oras turètu varžyti NATO galimybės naudoti oro galią, stabdant Rusijos kariuomenės judëjimą ${ }^{26}$.

Šiame scenarijuje JAV dislokuotų Baltijos regione dvi sunkias, vieną vidutinio lengvumo ir vieną oro desantinę divizijas, jūrų péstininkų ir specialiuju pajègu ekspedicines grupes, oro gynybos brigadą ir korpuso lygio logistinès paramos vienetus. Jūrų pajègos dislokuotų nuolatinès parengties desantinę gru-

${ }^{26}$ Larson E.V., Eaton D., Elrickn P., (note 26), p. 69. 
pę, tris arba keturis Aegis klasės kreiserius arba eskadrinius minininkus, P-3 pakrančių apsaugos ir nepilotuojamų Predator lèktuvų eskadronus, elektroninès kovos ir žvalgybos priemones, kovinès paramos ir palaikymo pajëgumus. Didžioji Britanija prisidètu šarvuota divizija, keturiais kreiseriais ir grupę Tornado naikintuvų. Vokietija atsiųstų tankų diviziją, kelias fregatas, minų medžiotojus ir povandeninius laivus ir grupę Tornado naikintuvų. Olandija prisidètų fregatomis, ir kartu su Norvegija dislokuotų F 18 grupę. Lenkija padètu mechanizuota pėstininkų brigada, o Švedija ir Suomija - kai kuriais Śiaurès brigados elementais.

Rusija siektu užkirsti kelią NATO pajègu pritraukimui. Dèl to Rusijos karinès oro pajėgos stengtųsi perimti pakrančių bei uostų kontrolę, užimti Latvijos ir Estijos sostines. Kartu Rusijos pajėgos Karaliaučiaus srityje stengtųsi uždaryti Lenkijos - Lietuvos sieną, kad pro čia negaletu patekti NATO šaliu pajėgos. Rusija kiek iggalėdama stengtųsi politiškai ir karine prasme atskirti JAV nuo jos sajungininkų Europoje, per kurių teritoriją būtų teikiama pagalba Baltijos šalims - Vokietiją, Belgiją ir Olandiją. Tam būtų naudojama toliašaudè artilerija, stengiamasi sugadinti kelius, geležinkelius, sugriauti tiltus. Rusija stengtųsi įsilaužti į elektronines NATO pajėgų valdymo sistemas, sugadinti elektroninius ryšius bei tinklus.

RAND manymu, tikimybė, jog Rusija pasiektų Lenkijos neutralumo ir ši nepraleistu NATO pajègu per savo teritoriją, nėra didelè. Todèl Rusija bandytu sukelti neigiamą Vokietijos visuomenės nuomonę dèl šios šalies dalyvavimo kariniuose veiksmuose Baltijos valstybėse. Radikaliau nusiteikę šios šalies žalieji bei kitos antiamerikietiškos grupuotės netgi galètų bandyti trukdyti čia dislokuotai JAV kariuomenei judèti link Lenkijos. Pagrindinėmis galimomis NATO kariuomenès priartëjimo vietomis laikomos Baltijos jūra bei Lietuvos - Lenkijos pasienis. Tačiau panaudoti Baltijos jūros prieigas numatoma tik karo veiksmu pradžioje, nes vẻliau Rusija galètų čia sutelkti pakankamą kiekị sparnuotuju raketu, kurios keltu grésmę NATO laivynui.

Lenkijos oro bazès būtų svarbiausios, vykdant oro operacijas. Tačiau permetant pajègas iš kontinentinès JAV ypatingai svarbi taptu Vokietijos, Olandijos ir Belgijos infrastruktūra ir susisiekimo keliai. JAV pajėgų Europoje vadas pirmiausia turètų pareikalauti iš sajungininkų žinių apie šių šalių turimus pajėgumus. Todèl pagrindine prieigos vieta laikomas sausumos koridorius tarp Karaliaučiaus srities ir Baltarusijos. Scenarijuje nurodoma, kad greitam NATO pajègu judèjimui labai padètų išplètota keliu, geležinkelių ir kita infrastruktūra Šiaurès Rytų Lenkijoje bei Lenkijos - Lietuvos pasienyje. Taip pat labai svarbiu laikomas Baltijos valstybiu jūrų bei oro uostų atitikimas NATO standartams bei jų pasirengimas priimti NATO karo laivus ir lèktuvus. Tokia pajėgų konfigūracija leistų NATO sẻkmingai ginti Baltijos šalis scenarijuje numatytų ivykiu pagrindu.

Apibendrinant, galima daryti išvadą, kad bene visos Baltijos šalių apginamumo analizės rodo, kad NATO turi pakankamai karinių pajėgumų efektyviai atgrasinti priešininkus. JAV darytos studijos netgi leidžia daryti prielaidą, kad JAV net ir be sajungininku pagalbos galètų užtikrinti Lietuvos gynybą regioninio konflikto atveju. Tačiau sajungininku - Vokietijos, Didžiosios Britani- 
jos, Danijos, Lenkijos - parama smarkiai padidintu JAV galimybes sėkmingai veikti regione. Svarbiausias iššūkis užtikrinant plačiojo atgrasinimo efektyvumą būtų ne karinis aljanso pajègumas, o potencialių agresorių įsitikinimas, kad karinè jèga bus panaudota.

Lietuvai ypatingai svarbu, kad potencialus agresorius negalètų sėkmingai atgrasinti jos sajungininkus nuo pagalbos jai tiekimo. Regioninio konflikto atveju egzistuoja didelè tikimybė, jog kai kurios Europos NATO valstybės taptu psichologinių Lietuvos priešininkų operacijų taikiniu. Šių operacijų tikslas būtų labai paprastas - suformuoti viešają nuomonę nepalankią Europos valstybiu karinių pajègų dalyvavimui ginkluotame konflikte ir karinès pagalbos Lietuvai tiekimui. Būtent tai, o ne karinio pajėgumo silpnumas, yra silpniausia Lietuvos išplèstinio atgrasinimo dalis. Todèl pats svarbiausias Lietuvos atgrasinimo strategijos elementas turi būti psichologinio atgrasinimo patikimumo užtikrinimas ir sajungininkų garantijų užtvirtinimas.

\section{Atgrasinimo psichologinio patikimumo užtikrinimas}

Atgrasinimas žlunga, kai atgrasinančioji valstybè ar jų sajunga, nors ir stengiasi, bet nesugeba perduoti oponentui savo ketinimu gintis ir priešintis. Lietuva, kartu su sajungininkais, gali neatgrasinti, jei potencialus agresorius tiki, jog Lietuva nesipriešins, arba kovos nelabai stipriai (nepriklausomai nuo pajègų dydžio); jei jis tikès, kad karas bet kuriuo atveju yra neišvengiamas; arba jis yra visiškai abejingas grèsmėms. Dažnai atgrasinimo sẻkmẻ nepriklauso nuo pajègų dydžio - siunčiami signalai yra ignoruojamai, o agresija įvyksta, nes tam jaučiamas didelis spaudimas iš valstybès viduje.

Atgrasinimo teorijos leidžia išskirti keturias psichologinio patikimumo užtikrinimo sritis, kurioms didelį dèmesį turètų skirti Lietuvos strategai:

- Dažnai vidinė politinè situacija gali versti lyderius griebtis vienų ar kitu karinių priemonių kitų šaliu, pavyzdžiui, Lietuvos, atžvilgiu. Agresija gali įvykti, net jei karo metu patirti nuostoliai bus didesni už gautą naudą. Tam tikrų Lietuvos kaimynių politinei vadovybei neveikimas dažnai gali būti labai skausmingas pats savaime - net ir pralaimètas karas kartais gali būti mažiau skausminga alternatyva už nieko neveikimą ar pasyvią politiką. Todèl valdančiojo režimo išsaugojimas gali tapti svarbesniu prioritetu negu kaštai patirti agresijos metu.

- Potencialūs agresoriai linkę koncentruotis ị savo vidinius poreikius, pavyzdžiui, vidinį politinị spaudimą, ir ignoruoti išorinius veiksnius, įskaitant atgrasinančiojo elgesi. Šiuo atveju agresija vykdoma, kai jai yra poreikis, o ne galimybe $\dot{e}^{27}$. Ypatingai per krizes, agresoriaus mąstymo procesas yra nukreiptas vidun (ang. inward looking), todèl Lietuvos ar jos sajungininkių siunčiami signalai gali būti ignoruojami.

\footnotetext{
${ }^{27}$ Lebow R. Between Peace and War. The Nature of International Crisis, Baltimore: Johns Hopkins
} University, 1981, p. 274-277. 
- Valstybių vadovai dažnai linksta į gražias svajones (ang. wishful thinking), jie siekia išvengti įtampos, kurią gali sukelti nepageidautina informacija apie priešininku pasiekimus. Tokia psichologija sustiprèja per krizes ir stresus, ir ypač veikia sutrikusios psichikos autoritarinius lyderius. Tokie lyderiai yra praktiškai neatgrasinami.

- Lyderiai nemėgsta blogų žinių ir jų nesiklauso. Biurokratinis aparatas norėdamas įtikti savo politiniams vadovams jas dažnai iškraipo ir interpretuoja skirtingai ${ }^{28}$. Krizès metu dèl patiriamo spaudimo tampa dar sunkiau priimti apgalvotus ir racionalius sprendimus. Pavyzdžiui, RAND Baltijos šalių scenarijuje karinès agresijos motyvas yra surišamas su rusakalbių padetimi. Vyraujant emocijoms, racionalūs paskaičiavimai gali būti nustumti į antrą planą.

Visi šie faktoriai lemia, kad vien gynybinio potencialo didinimas arba trečiuju šalių saugumo garantijos pačios savaime negarantuoja atgrasinimo patikimumo. Lietuva turi ne tik plètoti pajègumus, bet ir įtikinti potencialiu priešininkų lyderius, kad šie pajègumai bus panaudojami, o sajungininkų parama užtikrinta. Lietuvai svarbiausias tikslas - įtikinti potencialu priešininką, kad kariniu priemonių naudojimas Lietuvos atžvilgiu jam nėra naudingas. Tai teoriškai galima padaryti netgi neturint jokių karinių pajẻgumų - skleidžiant dezinformacija, slepiant nesamus pajėgus ir kitomis priemonemis bandant apgauti agresoriaus žvalgybos tarnybas ar valstybių lyderius. Aišku, tokia strategija būtų labai rizikinga ir modernių komunikacijų amžiuje greitai žlugtų. Todèl Lietuva turi imtis kitokių priemonių siekdama užtikrini patikimą atgrasinimą.

Psichologinio patikimumo problemos yra aiškiai suvokiamos pagrindinių Lietuvos įstatymų ir strategijų kūrëjų. Lietuvos nacionalinio ir karinëje strategijoje išreiškiama bei įstatymuose įtvirtinta prievolè gintis ir priešintis nepaisant nuo to, kokiomis pajègomis atakuoja priešininkas. Toks įsipareigojimas paremtas atitinkamomis priemonėmis, o jo nevykdymas gali vesti net prie baudžiamosios atsakomybès. Tokiu būdu Lietuva iš anksto bando įtikinti potencialius agresorius, kad karinis ir nekarinis pasipriešinimas neišvengiamas - net jeigu politiniai lyderiai ir nuspręstų nesipriešinti, kariuomenės vienetų vadai vadovaudamiesi iš anksto parengtais veiksmu ginkluotam užpuolimui atremti planais, atsižvelgdami į susidariusią karinę situaciją, pagal operacinio vadovavimo grandinę nedelsdami įsako pasipriešinti agresoriui ginklu ${ }^{29}$. Sprendimu prièmimo proceso decentralizacija Lietuvoje naudojama kaip viena pagrindinių priemonių iš anksto perduoti kitoms valstybėms informaciją, kad pasipriešinimas neišvengiamas. Taip aiškiai ir griežtai pateiktos nuostatos nesugebètu iškraipyti kitos valstybės biurokratinis aparatas ar kiti informacijos valstybiu lyderiams pateikèjai.

Valstybės įvaizdžio kūrimas yra svarbi psichologinė atgrasinimo užtikrinimo priemonė. Jei valstybẻ užsienyje suvokiama kaip stipri, vieninga, ištverminga, ar netgi karinga, grèsminga, kerštinga, tuo geriau atgrasinimui. Valstybės sugebẻjimo priešintis perdavimas išorèn verčia padidinti numanomus ag-

\footnotetext{
${ }^{28}$ Rhodes E., (note 15).

${ }^{29}$ Lietuvos karinés gynybos strategija, (nuoroda 2), p. 16.
} 
resoriaus kaštus konflikto atveju. Kita svarbi Lietuvos veikimo kryptis - nekurstyti negatyvių nuotaiku potencialaus agresoriaus gyventojų tarpe. Labai svarbu, kad maža valstybė netaptų vidinių agresoriaus problemų sprendimo ịkaite, i kurią nedemokratiniu valstybiu lyderiai galètu nukreipti nepatenkintu gyventoju pyktį. Valstybė suinteresuota, kad kitu valstybių lyderiai dèl savo politikos nesėkmių neužsipultų Lietuvos ir ji nebūtų įvardinama kaip jų problemų šaltinis. Dabar situacija nėra palanki Lietuvai. Pavyzdžiui, viešosios nuomonės apklausos rodo, kad Rusijos gyventojai suvokia Baltijos šalis kaip labiausiai priešiškas Rusijai valstybès - Latviją kaip priešiškiausią apibūdina 49 procentai, Lietuvą - 42, Estiją - 32 procentai rusų. Net Gruzija, Ukraina ir JAV vertinama geriau ${ }^{30}$. Situacija Baltarusijoje yra geresnè, nors ir jos nedemokratinis režimas gali panaudodamas įvairius metodus vaizduoti Lietuvą ar kitas NATO valstybes, ypatingai Lenkiją, kaip priešiškas šalis, kurias galima būtu paspausti naudojant karines priemones. Ypatingai didelis pavojus, jei negatyvių sentimentų banga sutaptų su grėsme paties autoritarinio režimo išlikimui. Tokiu atveju valstybių vadovų veiksmai gali būti neprognozuojami ir sunkiai atgrasinami.

Saugumą ir pasitikẻjimą didinančios priemonès, dažni valstybių vadovu kontaktai galètų leisti sumažinti tarpusavio nesusipratimų ir vienas kitam siunčiamų signalų iškraipymo riziką. Geri asmeniniai valstybių vadovų kontaktai ir glaudūs ryšiai su kitų valstybių pareigūnais įtakojančiais sprendimus susijusius su Lietuvai rūpimais klausimais, leistų sukurti atvirumo ir pasitikëjimo atmosferą. Deja, dẻl biurokratinio aparato uždarumo ir griežtos biurokratinės hierarchijos Lietuvos rytiniuose kaimynuose ši strategija yra sunkiai igyvendinama, bet ji neabejotinai turètu veikti bendraujant su nevyriausybinèmis organizacijomis arba akademinėmis bendruomenėmis. Kitų valstybių atstovai turi būti supažindinami su Lietuvos pasirengimu gynybai ir sajungininku garantijų tvirtumu, ekonominių santykių nauda ir Lietuvos ketinimais jų valstybių atžvilgiu.

Sajungininku paramos užsitikrinimas visada buvo svarbus atgrasinamasis veiksnys Lietuvos strategijoje. Trečiujų šalių suteikiamos garantijos visada turi papildomų trūkumų - įtikinti priešininką, kad kita šalis aukos savo kariu gyvybės vardan kitos valstybės interesu yra ganėtinai sunku. Istorija rodo, kad išplèstinis atgrasinimas kartais nesuveikia, pavyzdžiui, 1939 m. Prancūzijos ir Didžiosios Britanijos suteiktos garantijos Lenkijai neatgrasė Vokietijos nuo agresijos. Dar sunkiau yra užtikrinti branduolinį išplèstinį atgrasinimą patikèti, jog valstybė pasirengusi išgyventi branduolinį holokaustą vardan trečios šalies likimo, yra praktiškai neįmanoma. Todèl Lietuvos ir NATO gynybos planuotojai visada turi atsižvelgti ị suteikiamų garantijų patikimumą ir vidinius potencialaus agresoriaus poreikius bei motyvaciją.

Iš anksto užfiksuoti ịsipareigojimai ir planai yra svarbus psichologinis NATO saugumo garantiju pagrindas. Ši nuostata galioja ne tik nacionaliniu, bet ir tarptautiniu lygiu. Lietuva visada stengėsi įtraukti trečiujų šalių saugumo garantijas siekdama sustiprinti atgrasinimo efektyvumą. Lietuvos strategai supranta, kad krizės metu duotais naujais kariniais ir politiniais įsipareigojimais

${ }^{30}$ Социально-политическая ситуация в России в мае 2005 г., Аналитический центр Юрия Левады, http://www.levada.ru/press/2005060100.html, 20050601. 
siunčiami signalai dažniausiai neturi laukiamo efekto. Pavyzdžiui, Peter Karlsten, Peter Howell ir Artis Allen analizuodami JAV galimybes užtikrinti išplèstinį atgrasinimą, daro išvadą, kad krizei jau įsibègëjus, papildomų pajègų perdislokavimas, laivu eskadru siuntimas beveik neturi jokio empirinio ryšio su agresijos tikimybe ${ }^{31}$. Dèl motyvuoto nukrypimo, krizès metu agresorius dažniausiai lieka aklas tokiems signalams. Todèl Lietuva privalo turèti ne popierines, net iš anksto îtvirtintas realias saugumo garantijas, pagristas realiais planais ir patikrintas pratybomis. Dar iki narystės NATO, Lietuva savo gynybos planuose numate tam tikras vietas, per kurias gali ateiti karinè parama iš NATO valstybių. NATO oro policijos misija vykdoma iš Zoknių Aviacijos bazės ar kas dveji metai Lietuvoje vykdomos didelès karinès pratybos "Gintarinè viltis“, kur dalyvauja nemažai NATO valstybiu, yra geri atgrasinimo stiprinimo pavyzdžiai.

Svarbus psichologinių garantiju pagrindas yra jų aiškumas ir nuoseklumas. Kitą dieną po Lietuvos pakvietimo į NATO, George W. Bush kalba Vilniaus Rotušès aikštejje tapo JAV saugumo garantijų simboliu: „Mūsų Aljansas davè iškilmingą gynimo pažadą, taigi jei kas pasirinktų Lietuvą priešu, jis taptu Jungtinių Amerikos Valstiju priešu. Agresijos atveju drąsūs Lietuvos, Latvijos ir Estijos žmonés niekuomet nebebus vieni ${ }^{32}$ ".

Šie aiškiai išsakyti įsipareigojimai yra aiškus ir nedviprasmiškas signalas potencialiems agresoriams apie JAV veiksmus regione krizės atveju. Tuo labiau, kad beveik visi amerikiečiu politikai puikiai supranta, kad ịsipareigojimus teks vykdyti jei ne dèl pačios Lietuvos strategines svarbos, tai dẻl Amerikos pirmenybės pasaulyje išsaugojimo. Net NATO plètros priešininkas Ted Carpenter pabrěžia, kad ,jeigu Maskva staiga nutartu, jog Vašingtono buvimas regione yra jai nepriimtinas, JAV privalètu ginti ekonominiu ir strateginiu požiūriu visiškai nesvarbius sajungininkus. Jeigu kažkas mestų iššūkị Vašingtono įsipareigojimus, šis turètų rinktis iš blogo ir dar blogesnio scenarijaus ${ }^{\prime \prime 33}$. Jei JAV atsisakytų savo ịsipareigojimu, tai sukeltų rimtų abejonių dèl JAV įsipareigojimu psichologinio patikimumo kitose pasaulio dalyse. O jeigu JAV vis dèlto apsispręstų ginti savo sajungininkus, tai lemtų susidūrimą su kita branduoline valstybe. Todèl klausimas, ar amerikiečiai yra pasirengę aukoti Vašingtoną dèl Vilniaus likimo nèra labai svarbus. Daug tiksliau būtų klausti, ar JAV pasirengusi aukoti per penkis dešimtmečius sukurta aljansų ir sajungų sistema vardan Vilniaus likimo ir ką Lietuva turètų padaryti, kad atsakymas būtų neigiamas.

\footnotetext{
${ }^{31}$ Rhodes E., (note 15).

${ }^{32}$ Remarks to the Citizens of Vilnius by the President George W. Bush, November 23, 2002, http://www.state.gov/p/eur/rls/rm/2002/15452.htm, 20050601.

${ }^{33}$ Carpenter T. "Casting NATO Line Perilously Far to East", Washington Times, $2002 \mathrm{~m}$. sausio $12 \mathrm{~d}$.
} 


\section{Išplèstinio atgrasinimo užtikrinimo kryptys}

Po narystės NATO, sajungininkų suteiktos saugumo garantijos tapo vienu pagrindinių Lietuvos saugumo ramsčių. 2004 m. Lietuvos karinė strategija skelbia, kad „Atgrasinimo tikslas - itikinti potencialu agresoriu, kad jis susidurs ne tik su Lietuvos, bet ir jos sajungininkiu pajègomis ir patirs didžiulius nuostolius, kurie bus neverti siekiamo rezultato “34 .

Narystė NATO ir ES pakeitè Lietuvos atgrasinimo strategijos pobūdì, gynybos koncepciją ir kariuomenės plètros planus. Visuotinės gynybos sąvoka išnyko iš Lietuvos nacionalinio saugumo strategijos ir Lietuvos karinès strategijos, nors dauguma svarbių jos daliu, kaip pilietinis pasipriešinimas, liko gyvuoti. Narystė NATO turi ir kitokią reikšmę - po narystės Lietuva prisièmė įsipareigojimus ginti savo sajungininkus ir atgrasinti ju priešininkus. Lietuvos karinis potencialas nèra toks didelis, kad stipriai prisidètų, pavyzdžiui, prie Turkijos galimų priešininkų atgrasinimo, tačiau turi suteikti proporcingą savo dydžiui karinę ir kitokią paramą savo sąungininkų gynybai.

Visuotinès gynybos atsisakymas ir perëjimas prie kolektyvinės gynybos, kuri dabar apima ir prevencinius veiksmus, nubrėžia naujas atgrasinimo efektyvumo stiprinimo kryptis. NATO saugumo garantijos sustiprino Lietuvos saugumą, tačiau atgrasinimo koncepcijos požiūriu, trečiuju šalių saugumo garantijos turi svarbiu minusu, i kuriuos visada reikia atsižvelgti planuojant šalies gynybą. Pavyzdžiui, perẻjimas prie kolektyvinès gynybos pareikalavo perskirstyti lěšas, skirtas pasiruošti ilgam partizaniniam karui ar visuotiniam pasipriešinimui i ekspedicinių pajẻgumų kūrimą, o tai gali neigiamai veikti potencialaus priešininko įsitikinimą, kad jis įsivels į dešimtmečius truksiantį chaotišką konfliktą iš kurio jis negaus didelès naudos. Šiame skyriuje pateikiamos Lietuvos atgrasinimo strategijos stiprinimo kryptys, kurios leistų išnaudoti kolektyvinės gynybos sistemos teikiamus privalumus ir sumažintų jos trūkumus.

\subsection{Ankstyvojo įspèjimo ir žvalgybos sistemos}

Vienas svarbiausiu sėkmingo atgrasinimo užtikrinimo veiksniu yra ankstyvojo įspejjimo sistemų darbas. Priešininko pajègų stebejjimas ir jo lyderių veiksmu prognozavimas yra efektyvaus atgrasinimo sąlyga iš esmès. Sprendimas pradėti agresiją niekada nepriimamas per dieną, o, net jeigu jis ir būtų priimtas, pasiruošti operacijai reikalingas nemažas laiko tarpas. Pavyzdžiui, RAND studijoje manoma, kad Rusijai prireiktų 30 dienų nuo sprendimo prièmimo iki jo vykdomo pradžios ${ }^{35}$. Greito reagavimo pajègos gali pradèti veiksmus per mènesi, kitoms gali prireikti metų pasiruošimo. Efektyvus žvalgybos sistemų darbas turètų leistų Lietuvai, kaip ir kitoms regiono valstybėms, iš anksto nuspèti pasiruošimus agresijai arba jẻgos demonstravimui ir paruošti aukščiausius Lietu-

\footnotetext{
${ }^{34}$ Lietuvos karinè strategija, (nuoroda 3), p. 6-7.

${ }^{35}$ Larson E. V., Eaton D., Elrickn P., (note 26), p. 68.
} 
vos, NATO ir ES pareigūnus atsakomiesiems veiksmams. Jie galètų apimti krizių valdymo sistemos stiprinimą, šalies lyderiu paruošimą veikti įtampos laikotarpiu, gyventojų nuteikimą ìvairiems netikètumams, kariniu pajègumų stiprinimą ar net dalinę mobilizaciją ir užsienio šaliu paramos perdislokavimą.

Po narystes NATO Lietuvos sugebejimai numatyti kaimyninių valstybiu veiksmus smarkiai pagerëjo. Lietuvos žvalgybos sistema integravosi į bendrą NATO žvalgybos sistemą, kuri garantuoja greitą įvairios informacijos ir duomenu pasikeitimą tarp sajungininkų. Lietuvos oro erdvès stebëjimo ir kontrolès sistema tapo NATO integruotos oro gynybos sistemos dalimi, kuri užtikrina oro erdvės stebëjimo duomenu pasikeitimą. Visos šios priemonès leidžia iki minimumo sumažinti netikètumo faktoriu, prognozuojant agresyvius veiksmus Lietuvos atžvilgiu, o Lietuvos valdžiai sudaro pakankamą laiko tarpą imtis papildomų priemonių užtikrinant šalies gynybą.

Silpniausia Lietuvos vieta, kuriai ateityje reikètų skirti daugiausia dèmesio, yra analizės pajègumų stiprinimas. Tai apima tiek žvalgybinę veiklą vykdančias tarnybas, tiek akademines institucijas, vykdančias Lietuvos valdžios struktūrų užsakymus. Lietuva jau senokai stengiasi išsikovoti NATO ir ES šalyse „Rytų ekspertès“ vardą, nors jos analitiniai pajègumai pateikti naują požiūri ị i̇vykius Ukrainoje, Baltarusijoje, Moldovoje, Gruzijoje yra ganètinai menki. Lietuva neturi nè vieno bent kiek pasaulyje žinomo „smegenų centro“ ", kuris leistu skleisti ir aiškinti regione vyraujanti grèsmių supratimą, Vilniaus Universiteto Tarptautinių santykių ir politikos mokslų institutas, Lietuvos karo akademija ar kitų universitetu politikos mokslų katedros tik iš dalies užpildo šią nišą. Lietuvoje, Latvijoje ir Estijoje nèra karinès krypties analitinio centro.

Gebëjimas analizuoti ir svarbiausia suprasti užsienio valstybių vadovu sprendimus, ju gyventojų nuotaikas, politinių jẻgų išsidèstymą ir politiką Lietuvos atžvilgiu leistų adaptuoti Lietuvos siunčiamus signalus kitų valstybių atžvilgiu, pritaikyti juos konkrečioms situacijoms. Ypatingai svarbu, kad Lietuvos institucijų surinkta informacija greitai ir laiku, efektyvios krizių valdymo sistemos dèka, būtų pristatyta aukščiausiems valdžios pareigūnams, kad leistu priimti sprendimus tinkamu laiku.

\subsection{Dalyvavimas tarptautinèse operacijose}

Lietuvos dalyvavimas tarptautinėse operacijose padidina išplèstinio atgrasinimo efektyvumą padidindama sajungininkų politinius ir moralinius karinės jègos nenaudojimo kaštus karinio konflikto atveju. JAV, Didžiajai Britanijai ir kitoms valstybèms būtų sunku atsakyti panaudoti politines, ekonomines ar netgi karines priemones Baltijos regione, kai Lietuvos kariai rizikuoja gyvybe gindami bendrus Aljanso interesus Irake, Afganistane ir kituose karštuose pasaulio regionuose. Kad Lietuva turi galimybių dalyvauti tarptautinėse operacijose jau buvo irodyta per pastaruosius keletą metų. Specialiujų operaciju junginio kariai tris kartus sẻkmingai vykdè užduotis Afganistane, o $2005 \mathrm{~m}$. vasarą pradëjusi vadovauti Provincijos atkūrimo grupei Goro provincijose Afganistane Lietuva pirmą kartą savo istorijoje savarankiškai prisièmė atsakomybę už kitos valstybės vieno 
iš regionų stabilumo palaikymą. Vieną dieną gali atsitikti, kad dauguma Lietuvos karinių pajègumų bus perdislokuoti Artimuosiuose Rytuose arba Pietryčių Azijoje. Krizès atveju juos sugražinti atgal gali prireiktu gana nemažo laikotarpio, todèl Lietuva turès besąlygiškai pasitikèti sąjungininkų įsipareigojimas jos gynybai.

Valstybės renkasi ịvairius būdus, kaip rengti karinius vienetus tarptautinėms misijoms. Kai kurios valstybės, pavyzdžiui Suomija ar Rusija, karius i operacijas renka iš identifikuotu vienetų, pavyzdžiui, taikos palaikymo brigadụ. Toks modelis leidžia atrinkti geriausius karius, juos specialiai mokyti, taip minimizuojant nelaimingų atsitikimų ar klaidų riziką. Sio požiūrio silpnybė yra ta, kad jis valstybių viduje sukuria dviejų rūšių kariuomenes - vieną nacionaliniams, kitą - tarptautiniams uždaviniams vykdyti. Šios struktūros dažnai susipriešina, atsiranda nesveika įtampa, kuri mažina bendrą pajėgumą. Kitas modelis naudojamas šaliu, kurios perëjo prie profesionalios kariuomenes. Profesionalai turi tarnauti ten, kur juos siunčia, todèl visos pajègos be jokių išimčiu gali būti panaudotos operacijoms vykdyti. Tai garantuoja, kad visi kariuomenes pajègumui reikalui esant gali būti panaudoti kolektyviniams veiksmams, îskaitant paramą sajungininkams. Šis modelis yra brangesnis, tačiau efektyvesnis kolektyvinèse saugumo sistemose.

Lietuvoje galima rasti abiejų modelių elementu. Pagal krašto apsaugos ministro gaires: „Gynybos reformos tikslas yra pertvarkyti kariuomenę taip, kad $2014 \mathrm{~m} .10$ procentų Sausumos pajègumu galètų nuolat dalyvauti tarptautinėse operacijose, o 50 procentų. jų būtų tinkamai organizuoti, apmokyti ir apginkluoti ir bet kada galètų būti perdislokuoti už Lietuvos ribų “36.

Tai rodo aiškią orientacija link antrojo modelio valstybiu, nors įstatyminė bazė tam prielaidų kol kas nesudaro. Pagal šalies ịstatymus Lietuvos kariai į misijas vyksta savanoriškumo pagrindu. Savanoriškumo principas negalioja tik kolektyvinẻs gynybos operacijoms. Tai reiškia, kad norint pasiųsti į taikos palaikymo operaciją kuopos dydžio vienetą visi šimtas karių turi raštiškai patvirtinti, kad jie sutinka važiuoti. Statistika rodo, kad visada atsiras bet 15 procentų kariu, kurie dèl vienų ir kitu priežasčių atsisakys dalyvauti operacijoje. Todèl, dislokuodamas karinis vienetas visada bus papildomas kariais iš kitų daliniu, o tai labai neigiamai veikia perdislokuojamu pajėgų pasiruošimq bei didina incidentu galimybę.

Tačiau didžiausia problema slypi kitur - norint užtikrinti išplèstinio atgrasinimo efektyvumą, kariniai vienetai turi būti perdislokuoti į valstybę, kuri jaučia pavojų dar prieš prasidedant krizei. Iki karines agresijos momento, tai greičiausiai nebūtų Vašingtono sutarties 5 straipsnio operacija, taigi savanoriškumo principas galiotu. Todèl, jei $2014 \mathrm{~m}$. Turkija paprašytų pagalbos, ir NATO paprašytu Lietuvos ten dislokuoti „Geležinio Vilko“ brigadą, tai padaryti būtu labai sunku, nes iš visų daugiau kaip 5000 kariu, iskkaitant profesinès karo tarnybos karius, tektų surinkti panašus, kad jie sutinka važiuoti. Tokie apribojimai

${ }^{36}$ Prie sausumos pajėgumu, remiantis NATO apibrèžimu, priskiriami visi sausumos vienetai, galintys vykdyti kovines, kovinès paramos ir kovinio aprūpinimo užduotis sausumoje. Tai motorizuotoji pėstininkų brigada "Geležinis vilkas", Inžinerijos batalionas, Specialiujuc operacijų junginys, Tiesioginès paramos logistikos batalionas, Bendrosios paramos logistikos batalionas, Karo policija. Mokymo ir doktrinų valdyba ir Štabo batalionas neįskaičiuojami kaip neatitinkantys minèto kriterijaus. 
smarkiai sumenkina Lietuvos galimybes tiekti paramą sajungininkams krizių (ne karo) metu ir prisidèti prie jų atgrasinimo efektyvumo.

\subsection{Priimančios šalies parama}

Siekis užsitikrinti sajungininkų karinę paramą dar prieš prasidedant kariniams veiksmams, yra svarbi atgrasinimo efektyvumo salyga. Dabartiniu momentu, ji iškelia nemažai dilemu Lietuvos gynybos planuotojams. Šaltojo karo metu NATO planavo gintis nuo Sovietų Sajungos savo teritorijoje, todèl šalys esančios netoli Varšuvos bloko valstybės daug dèmesio skyrẻ atvykstančių sajjungininku paramos prièmimui. Tai reiškia, kad priimančioji šalis yra atsakinga už efektyvu ligoninių tinklo, ryšių sistemu, kelių ir geležinkeliu pritaikymą karo veiksmams.

Lietuvai pradejus integraciją į NATO, priimančios šalies pajėgumu kūrimas tapo vienu iš šalies gynybos prioritetu. Pradèta galvoti, kaip pritaikyti civilinę infrastruktūrą NATO reikmėms krizių atveju, Krašto apsaugos savanoriu pajëgoms pavestos atvykstančių pajėgų apsaugos, Logistikos valdybai - logistinio aprūpinimo funkcijos. Priimančios šalies paramos procedūros buvo konkrečiai išbandytos priimant NATO šalių orlaivius Zoknių oro uoste arba organizuojant didžiausias Baltijos šalyse pratybas „Gintarinè viltis“. Tai buvo gana menko dydžio operacijos, nepalyginamos su tomis, kurių prireiktu, jei karinio konflikto metu NATO valstybės nuspręstų dislokuoti Lietuvoje keletą diviziju ar netgi korpusu. Prieš Lietuvos gynybos planuotojus iškyla dilema ar tikslinga skirti didelius išteklius pasiruošimui priimti sajungininkus ar geriau juos panaudoti kitur, pavyzdžiui, dalyvavimui tarptautinèse operacijose.

Iki šiol nèra vieningos nuomonès šiuo klausimu. Iš vienos pusès, tokie pasiruošimai galètų pagreitinti NATO pajėgų atvykimą į Lietuva, užtikrintų efektyvesnị jų logistinį aprūpinimą šalies viduje, o tai buvo pažymėta RAND atliktoje Lietuvos apginamumo studijoje. Iš kitos pusės, šis brangiai kainuojantis pajėgumas neturi būti plètojamas dèl šiu priežasčių: Pirma, NATO šalys kuria ekspedicines pajègas, kurios gali veikti bet kuriama pasaulio šalyje, yra lengvai dislokuojamos ir save išsilaikančios. Pavyzdžiui, NATO reagavimo pajègos (ang. NATO Reaction Forces, NRF) turi veikti be jokios priimančios šalies paramos bet kurioje pasaulio vietoje. NATO nusprendus panaudoti NRF Lietuvos gynybai, jos poreikiai pasinaudoti vietine parama būtų minimalūs. Antra, NATO karinis pranašumas prieš kitas valstybes yra toks didžiulis, kad Lietuvos nepasirengimas priimti atvykstančių pajègų nepalenktų svarstyklių į priešininkų pusę. Trečia, grẻsmės atveju NATO greičiausiai imtųsi prevencinių veiksmų. Kaip neoficialiai pasakè vienas Aljanso pareigūnas“, o kas jums sakè, kad NATO ruošiasi jus ginti jūsų pačių teritorijoje?". NATO turi pajègumu, kurie gali sunaikinti priešininką bet kurioje pasaulio vietoje, todẻl šiuo požiūriu priimančios šalies paramos pajėgumai beveik nereikalingi.

Taigi, Lietuvos investicijos į priimančios šalies pajègumus stiprina šalies atgrasinimo potencialą, tačiau mažiau prisideda prie atgrasinimo efektyvumo užtikrinimo nei, pavyzdžiui, ankstyvojo įspëjimo sistemų stiprinimas ar dalyvavimas tarptautinėse operacijose. 


\subsection{Ginklụ kontrolès mechanizmai}

Ginklų kontrolès mechanizmai stiprina atgrasinimo efektyvumą leisdami stebèti turimos ginkluotés kiekį kaimyninių valstybių tarpe, jas inspektuoti. Lietuva dalyvaudama ginklų kontrolès priemonėse, galètų dalyvauti nustatant kitose valstybėse dislokuotos ginkluotès kiekį, gauti papildomos informacijos apie kitų valstybiu karinius pajėgumus. Ginklų kontrolè taip pat yra svarbi pasitikejjimą skatinanti priemonė, leidžianti valstybẻms dalintis turima informacija ar užmegzti draugiškus santykius su kitu valstybių pareigūnais. Tokiu būdu sumažèja saugumo dilema, o valstybiu ginklavimuisi nustatomos visiems priimtinas susitarimas, dèl kurio nei viena valstybè neigyja didelio pranašumo. Reikia pažymèti, kad ginklų kontrolès režimas turi ir daugybę trūkumų ir silpnybiu, kuriais pasinaudojant galima apeiti nustatytus apribojimus, arba argumentuojant techninėmis priežastimis neisileisti užsienio inspekcijų.

Ginklų kontrolès sąryšis su atgrasinimo strategija yra paprastas - pagal atgrasinimo logiką, net ir numanomas priešininko sustiprejjimas gali išprovokuoti agresiją ir prevencinius smūgius, jei valstybė prognozuoja, kad jègų pusiausvyra ateityje pablogės. Pavyzdžiui, staigus Lietuvoje esančio karinio potencialo didejimas gali padidinti laiko spaudimą potencialiam agresoriui imtis konkrečių veiksmu, o atsirandantis spaudimas vestų prie neracionalių spaudimų ir greitų alternatyvų paieškos. Teoriškai, ginklų kontrolès režimai, turètų užkirsti kelią tokiems netikètumams. Antra, ginkluotės lubų nustatymas sukurtų savotišką galios pusiausvyrą regione, ir nesuteiktų galimybės Lietuvos priešininkams pirmiems smogti lemiamą smūgị.

Lietuva jau prisijungé prie daugumos ginklų kontrolès mechanizmų. Dar $1993 \mathrm{~m}$. Lietuva prisijungè prie Vienos dokumento, kuriuo įsipareigojo teikti informaciją apie pagrindines karines pratybas ir turimą ginkluotę. $1999 \mathrm{~m}$. Lietuva paskelbè norinti prisijungti prie Iprastinès ginkluotės Europoje (ang. Conventional Forces Europe, CFE) sutarties, kuri reglamentuoja ịprastinès ginkluotés kiekị Europos žemyne. 2002 m. Lietuva prisijungè prie Atvirojo dangaus sutarties, leidžiančios kitoms valstybėms atlikti žvalgomuosius skrydžius virš Lietu$\operatorname{vos}$ teritorijos $^{37}$. Lietuvai įstojus į NATO, jai galioja ir $1997 \mathrm{~m}$. Rusijos - NATO chartijos dalis, kuri skelbia, jog „NATO narès pakartoja, kad jos neturi ketinimu, planų ir priežasčių dislokuoti branduolinius ginklus naujų valstybių narių teritorijose, ir nemato bei ateity nematys jokio reikalo keisti NATO branduolinę politiką bei ginklų dislokaciją“38.

Didžiausias iššūkis Lietuvai ateityje bus prisijungimas prie CFE sutarties, kuri Rusijai yra svarbi kaip JAV karinio aktyvumo regione ribojimo elementas. Adaptuota CFE sutartis sudaryta taip, kad 1999 m. priimtu i NATO nauju

\footnotetext{
${ }^{37}$ Atvirojo dangaus sutartis reglamentuoja prisijungusiuju valstybiu orlaiviu stebëjimo skrydžių virš kitu sutartyje dalyvaujančiu valstybių teritorijos tvarką. Ši sutartis yra svarbi pasitikẻjimą ir saugumą stiprinanti priemonė. Užsienio reikalu ministerija. „Lietuva prisijungė prie Atviro dangaus sutarties", Užsienio reikalų ministerija, $2002 \mathrm{~m}$. liepos $22 \mathrm{~d}$. http:// www.urm.lt/view.php?cat_id=3\&msg_id=1266, 20030901.

38 "Founding Act on Mutual Relations, Cooperation and Security between NATO and the Russian Federation“, NATO, http://www.nato.int/docu/basictxt/fndact-a.htm, 20030901.
} 
nariu teritorinès „lubos“ prilygsta nacionalinėms „luboms“, tai yra, sąungininkių pajègas valstybės gali priimti tik sumažindamos nacionalines pajėgas. Rusijai tai suteikia garantiją, kad prie jos sienų naujose NATO narèse nebus sutelkta daug iprastinès ginkluotès ${ }^{39}$. Švedijos tarptautinių taikos tyrimo centro analitiko Z. Lachovskio nuomone, Baltijos šalys be didesnių varžymu galès didinti ginkluotę, juo labiau kad per dešimt metų dviejų tipu ginkluotès - koviniu lèktuvų ir tankų jos net nenumato įsigyti. Krizès pradžioje JAV veikiausiai galètų dislokuoti Baltijos valstybėse apytiksliai vienos brigados dydžio pajègas - 153 tankus, 241 šarvuoti, 140 artilerijos vienetu. Net ir pasiekus šiuos skaičius, Lietuvos, Latvijos ir Estijos teritorijose bus sutelkta gerokai mažiau ginkluotès nei vakarineje Rusijos dalyje ar Baltarusijoje, todèl turimų karinių pajėgumų neužtektu efektyviam atgrasinimui užtikrinti. Baltijos valstybės turètų siekti gauti ginkluotès daug didesnes, nei Z. Lachovskio numanomas „lubas“, kurios daugmaž atitiktų Lietuvos kaimynystëje sutelktos ginkluotės tankį. Kitu atveju, atgrasinimo efektyvumas gerokai sumažètú.

Ginklų kontrolès režimai Baltijos šalyse reiškia, kad patikimam atgrasinimui garantuoti JAV taip pat negalès naudoti labai veiksmingu priemoniu, pavyzdžiui, dislokuoti branduolinio ginklo ar steigti didelių karinių bazių. Greičiausiai JAV ir sąungininkai bus pasiryžę šitaip elgtis dèl politinių priežasčiu - amerikiečiu buvimo ribojimas ir Baltijos valstybiu prisijungimas prie ginklu kontrolės režimo suteikia Rusijai garantiją, kad kilus NATO ir Rusijos santykiu krizei Baltijos šalyse nebus sukauptas karinis potencialas, grasinantis Rusijos saugumui. Tai politinè kaina, kuri yra neišvengiama NATO plètros dalis. Iš kitos pusès, Lietuva karu su sajungininkais galès dalyvauti tikrinant kitų šaliu karinius dalinius, gauti informaciją apie ju plètros planus ir gynybos politikos kryptis. Todèl Lietuvos didesnis įsitraukimas i i ginklu kontrolès mechanizmus yra svarbi, nors ir ne pagrindinė pastangų, siekiant užsitikrinti patikimą atgrasinimą, dalis.

\subsection{Gynybinių pajègumų stiprinimas}

NATO kolektyvinės saugumo garantijos ir nacionalinių karinių pajėgumu plètra ateityje išliks Lietuvos atgrasinimo strategijos pagrindas. Lietuva, kaip maža valstybė, yra pajėgi savarankiškai reaguoti į karines provokacijas ar neramumus, tačiau ginkluoto konflikto metu Lietuvos kariuomenės veiktų kaip sudètinè jungtinių sajunginiu pajėgų dalis. Šias pajėgas sudarys įvairiu šaliu perdislokuojami daliniai, pajègūs atgrasinti priešininkus ar atremti agresiją bet kurioje aljanso vietoje - ar tai būtų Turkija, Lietuva ar Rumunija.

İsiliejus į NATO kolektyvinès gynybos sistemą, Lietuvos kariuomenès plètros planai buvo radikaliai peržiūrèti. Vienos penkiu planuotų statistišku brigadų nuspręsta kurti vieną perdislokuojamą brigadą, peržiūrètos teritoriniu pajėgų užduotis, logistikos sistema perorientuota ị tarptautinių operacijų rèmi-

${ }^{39}$ Lachovski Z. The Adapted CFE Treaty and the Admission of the Baltic States to NATO. Stockholm International Peace Research Institute, 2002, p. 10. 
mą. Lietuvos karinė strategija skelbia, kad „Lietuvos karo meto koncepcija pagrịsta visų sajungininkių ịsipareigojimu bendrai pasipriešinti galimai agresijai. Šiems įsipareigojimams vykdyti Lietuva pasitelks pajejgumus, kuriu pagrindas Nuolatinès parengties brigada ir jos paramos bei aprūpinimo vienetai ${ }^{\prime 40}$.

Igyvendinus gynybos reformą beveik visi Lietuvos kariuomenės vienetai bus paruošti dalyvauti tarptautinèse operacijose ir igyvendinti nacionalinius uždavinius. Šie pajègumai išliks svarbi atgrasinimo strategijos dalis, tačiau jie turi būti modernizuojami, aprūpinami naujomis ginklų sistemomis ir ryšių priemonėmis, kad galètų veikti kartu su sajungininkų pajëgomis. Net oficiali Krašto apsaugos ministerijos parengta ilgalaikè kariuomenès plètros plano dalis pripažista, kad:

Nors Lietuvos kariuomenės pertvarkymo planai sajungininkų yra gerai vertinami, o jos kariniai vienetai nuolat dalyvauja tarptautinèse operacijose, tačiau ji turi tik ribotus pajėgumus tinkamai vykdyti ilgalaikes karines operacijas moderniame mūšio lauke. Sparčiai besivystant karinėms technologijoms, kyla grèsmė, kad ateityje Lietuvos kariuomenė, neturẻdama modernios ginkluotès ir karinès technikos, dèl technologinio atotrūkio bus nepajėgi veikti kartu su sajungininkais ${ }^{41}$.

Modernizavimas turi išlikti svarbiausiu Lietuvos kariuomenès plètros prioritetu. Net ir neatsižvelgiant i kolektyvinès gynybos garantijas, kariuomenės modernizavimas smarkiai pakeltų atgrasinimo efektyvumą. Konvencinį atgrasinimo patikimumą ypač stiprina spartus konvenciniu ginklų tobulëjimas pastaraisiais dešimtmečiais padidèjo jų patikimumas, taiklumas, sparta, greitis ir tikslumas ${ }^{42}$. Šiuolaikiniai technologiniai atradimai sutvirtina gynybą - tikslios ir pakankamai paprastos raketos gali būti naudojamos prieš tankus ir lèktuvus, centrines puolimo figūras ${ }^{43}$. Moderni ginkluotė stiprina galimybes atgrasinti tik konvencinėmis priemonèmis ne tik ginantis, bet ir smogiant priešininkui jo paties teritorijoje. Tokios ginkluotès įsigijimas karinių planuotoju vèliau turès būti svarstomas, nors dèl finansinių galimybių stokos artimiausius dešimt metų tai sunkiai įmanoma.

Atgrasinimo koncepcijos požiūriu, Krašto apsaugos ministerijos parengti Lietuvos kariuomenès modernizavimo planai gali pasirodyti mažai ambicingi, lyginant su Lietuvos kaimynų vykdomomis programomis. Rusijos ir Baltarusijos gynybos biudžetas pastoviai auga, tuo tarpu Lietuva pagal bendrojo vidaus produkto dali skiriamą gynybai NATO šaliu tarpe yra paskutiniuju gretose. Lietuvos gynybos biudžetui smarkiai atsiliekant nuo kaimynių, kyla grėsmė, jog Lietuvos atgrasinimo strategija remsis išimtinai sajungininkių ịsipareigojimais, o pati Lietuva nesugebės tinkamai prisidèti prie savo sajungininkų gynybos.

\footnotetext{
${ }^{40}$ Lietuvos karine strategija, (nuoroda 3), p. 10.

${ }^{41}$ Lietuvos krašto apsaugos sistemos pletros programa, (nuoroda 9).

${ }^{42}$ Hopkins J. C., Maaranen S. A. Nuclear Weapons in Post Cold War Deterrence, In Post-Cold War Deterrence. Washington: National Academy Press, 1997, http://bob.nap.edu/html/pcw/ Dt-g3.htm, 20050228.

${ }^{43}$ Encyclopeadia Britannica, (note 12).
} 


\subsection{Ekonominès priemonès}

Atgrasinimo teorija pabrèžia ne tik karinius kaštų suteikimo klausimus. Karas ar agresija dažnai reiškia santykių su agresijos objektu ir jos sajungininkais nutraukimą, tikètinos tarptautinės sankcijos. Šiuolaikiniame pasaulyje tai reiškia didžiulius kaštus kariaujančioms valstybèms, ypač prarastą pelną iš tarptautinės prekybos. Ekonominių ryšių nutraukimas smarkiai atsilieptų ekonominėms interesu grupėms. Neatsitiktinai JAV Užsienio politikos taryba savo raporte apie Šiaurès Europos šalis pabrěžia, kad ne tiek svarbu, ar Baltijos šalys yra apginamos, kiek įsipareigojimas, kad prievartos prieš jas atveju, Rusija susilauks griežto NATO atsako prieš vertingus Rusijos išteklius. Tie ištekliai nebūtinai būtų kariniai. Tai turètų atgrasinti Rusiją nuo agresijos prieš Baltijos šalis ${ }^{44}$.

Dèl agresijos Lietuvos teritorijon, neišvengiamai siektų tarptautinės sankcijos. Sankcijos turètų gali būti daugiausia ekonominio pobūdžio - paskolu nutraukimas, prekybos suvaržymai ir investiciniu projektų išaldymas. Kuo svarbesnè Lietuva bus užsienio šalimis, kuo didesnè bus užsienio investicijos į Lietuvos ūkì, tuo sankcijų tikimybė augs. Narystė Europos Sajungoje smarkiai sustiprino atgrasinimo strategijos sėkmės šansus. Nors Europos Sajunga ir nesuteikia formaliu saugumo garantiju, tačiau sunku įsivaizduoti, jog blokas galètu ramiai žiūrèti i grasinimą jẻga vienai iš savo nariu, jau nekalbant apie karinę agresija.

Europos Sajunga turi realių ekonominių svertu, kuriais galètų veikti kitų šaliu, ypatingai Rusijos politiką. Rusijos užsienio prekyboje Europos Sajungos valstybių dalis sudaro apie 50 procentų. Tuo tarpu Rusijos dalis Europos Sąjungos prekyboje yra tik 4 procentai. Taigi ekonominiu atžvilgiu Rusija yra priklausoma nuo Europos Sajungos, o ne atvirkščiai. Vienintelè išimtis yra energetikos sektorius. Iki plètros pusę Rusijos eksporto i Europos Sajungos šalis sudare nafta ir dujos (tai yra apie 20 proc. bendro Europos Sajungos naftos ir 45 proc. duju importo $)^{45}$, o prièmus naujas nares, kurios yra Rusijos dujų importuotojos, ši dalis dar labiau padidejo ${ }^{46}$. Taigi, santykių su Rusija nutraukimas būtų skausmingas abiem pusėms, tačiau Rusijos nuostoliai būtų gerokai didesni.

Ekonominės priemonės yra svarbios užtikrinant patikimą atgrasinimą, tačiau vien jomis remtis negalima. Visų pirma, jų poveikis būtų jaučiamas tik nuo agresijos momento, kai sprendimas pulti jau būtu priimtas. Neracionalaus agresoriaus atveju, jų vaidmuo gali neturèti lemiamos reikšmės. Antra, autoritarinio režimo ịsigalëjimas labai pablogintų Lietuvos padètị, kadangi, autoritariniai lyderiai į ekonomini poveikị atsižvelgtų mažiau nei demokratinių šaliu

\footnotetext{
${ }^{44}$ Brzezinski Z., Larrabee F. „US Policy Towards Northeastern Europe“ (Independent Task Forces Report), Council on Foreign Relations, 1999, http://www.cfr.org/content/publications/attachments/Northeastern_Europe.pdf, 20050228.

${ }^{45}$ Perovic J. "Coming Closer or Drifting Apart? EU-Russia Partnership and EU Enlargement in Eastern Europe“" Center for Security Studies, ETH Zurich, 2003, http://www.isn.ethz.ch/ pubs/ph/details.cfm?v21=61682\&lng=en\&id=6831，2005 0228.

${ }_{46}$ Stratfor, "Russia Poised to Dominate European Energy", 2001 m. spalio 11 d. http:// www.stratfor.biz, 20030901.
} 
vadovai. Todèl didžiausia grèsmė būtų neprognozuojamų ir psichologiškai nestabilių politikų ir saugumo struktūrų atstovų įsigalëjimas Rusijos ir Baltarusijos viršūnėse. Pavojus slypi, kad krizès metu autoritarinių valstybių politiniai lyderiai yra linkę ignoruoti ekonominius faktorius, jie daugiausia dèmesio skiria karinių priemoniu naudojimui. Pasirengimas kariauti visada buvo atgrasinimo strategijos svarbiausias elementas, o autoritarizmo tendencijos Lietuvos kaimynystëje tik iliustruoja ekonominių priemonių nepakankamumą. Joms ateityje turètų būti skiriamas didesnis dėmesys, tačiau pačios savaime jos neatgrasins priešininku.

\section{Išvados}

Atgrasinimas yra vienas iš kertinių Lietuvos saugumo ir karinès strategijos akmenų. Nors tiksliai įvertinti Lietuvos atgrasinimo strategijos sẻkmę yra beveik neįmanoma, tačiau galima konstatuoti, kad iki šiol bandymai karinėmis pratybomis ar agresyviais šūkiais pagąsdinti Lietuvos politikus ar primesti savo valią nebuvo sèkmingi. Lietuvos saugumo ir gynybos politika nuo pat nepriklausomybès pradžios išliko tokia pati - kolektyvinès NATO saugumo garantijos, JAV intereso Europoje išlaikymas, dalyvavimas tarptautinės bendruomenės pastangose stiprinti saugumą nestabiliuose pasaulio regionuose. Rusijos ir Baltarusijos politikams nepavyko įrodyti, jog išplèstinio atgrasinimo taikymas Baltijos šalyse yra nepatikimas ar neigyvendinamas.

Iki narystės NATO Lietuvos atgrasinimo strategija buvo aiški atgrasinimo atsaku forma. Lietuva neturi ginkluotès, leidžiančios smogti priešininko teritorijon. Lietuva galëjo tik atgrasinti, stengdamasi neleisti priešininkui efektyviai kontroliuoti Lietuvos teritorijos ir pradèti ilgą partizaninį karą. Kitais žodžiais - Lietuvos strategija būtų neleisti priešininkui gauti apčiuopiamos naudos iš šalies teritorijos okupacijos ir karinès kontrolès. Tačiau ji turëjo porą esminių trūkumu: pirma, ji leido priešininkui blefuoti, žinant, kad Lietuva neturi beveik jokių karinių ir nekarinių pajègumų suteikti priešininkui kaštus pradinëje konflikto fazëje; antra, galima fait accomply situacija - užimti Lietuvos teritoriją ir bandyti derybomis gauti naudos; trečia, pačiai Lietuvai patirti kaštai būtu nepriimtini - valstybẻ būtų atblokšta porą dešimtmečiu atgal.

Po narystės NATO Lietuvos strategija pasikeite - jos pagrindiniu prioritetu tapo išplèstinio atgrasinimo užtikrinimas. Karine prasme tai reiškia karinių pajègumų Aljanso gynybai kūrimą ir teritorinių pajëgų pertvarkymą i ekspedicines pajėgas. Gynybos reforma leido padidinti Lietuvos įsipareigojimus savo sajungininkams, o tai užtikrino didesnị pastarujų aktyvumą Baltijos regione. Kolektyvinės gynybos sistemoje atgrasinimo sėkmę lemia aiškiai ir nedviprasmiškai įtvirtintos saugumo garantijos, o narystė Europos Sajungoje surišo Lietuvą ekonominiais, finansiniai ir kitais saitais su kitomis Europos valstybèmis. Šie ryšiai ir solidarumo nuostata leidžia Europos Sajungą laikyti svarbiu veiksniu prisidedančiu prie efektyvaus atgrasinimo užtikrinimo. 
Apibendrinant galima padaryti išvadą, kad Lietuvos atgrasinimo strategijos patikimumas yra užtikrinamas tiek nacionalinėmis priemonėmis ir procedūromis, tiek naryste NATO ir Europos Sajungoje. Siekiant dar didesnio atgrasinimo patikimumo, Lietuva turètų dar labiau sustiprinti darbą sajungininku visuomenėse, kuriant Lietuvos, kaip patikimos šalies įvaizdị. Tamprūs ekonominiai ryšiai, gynybinis bendradarbiavimas, finansinio sektoriaus integracija sajungininkų tarpe didintų nieko neveikimo krizės atveju kainą, nors patys nereikštų automatiškos paramos agresijos atveju. Ne mažiau svarbi užduotis Lietuvai - tai darbas potencialiu priešininkų visuomenėse, siekiant įtikinti Lietuvos pajejgumu ir valia priešintis bet kokiam bandymui karine jèga primesti savo valią. Mažai valstybei egzistuojančiai didesnių kaimynių apsuptyje tai nemažas iššūkis, kuriam atremti reikia pasitelkti ne tik praktines, bet ir gilias teorines žinias. 